\title{
الاحتياجات التدريبية لمعلمات رياض الأطفال من وجهة نظرهن بمحافظة الجبيل
}

إعداد

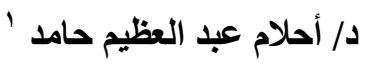

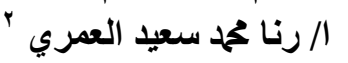

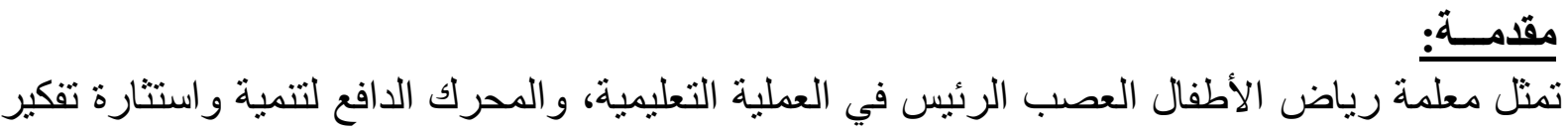
الأطفال من خلال البيئة المشجعة و المحفزة على اكتساب مهار ات التفكير، وما تستخدمه من أساليب وطر ائق مثيرة تتحدى العقل وتشجع على الاكتشاف، وتثري الخيال. فالعملية التربوية لا تعني شيئاً فعالاً

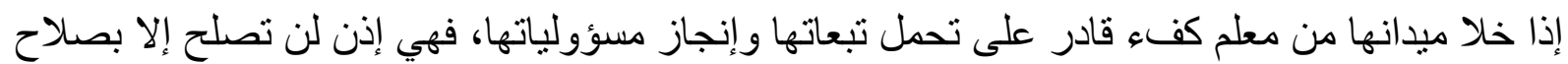

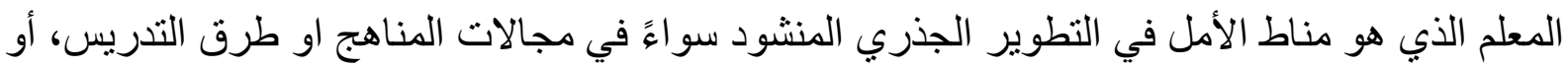

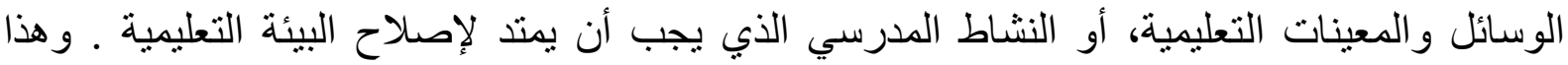
يفرض على المعلم أن يكون واسع الثقافة، ملماً بالمادة التي يدرسها وبأساليب التربية ووسائلها الحديثة

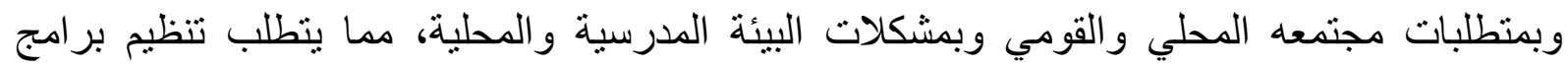
تدريبية لمواجهة الادوار و الوظائف المختلفة التي يفرضها الانفجار المعرفي واستخدام التكنولوجيا الحديثة في التعليم ـ فطبيعة المعرفة الناتجة عن الاكتشافات العلمية المتسار عة قد عدلت في مهام المعلم ووظائفه التقليدية وما ينبغي أن يقوم بتدريسه ـ فلم يصبح تعلم القراعة و الكتابة ومبادئ الحساب كافياً للعملية

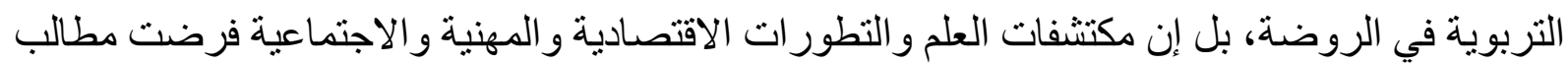

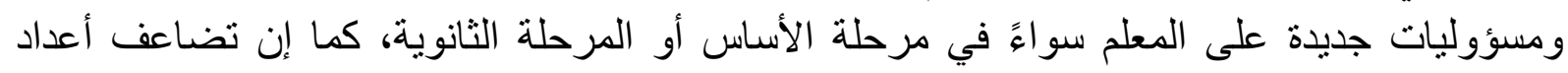

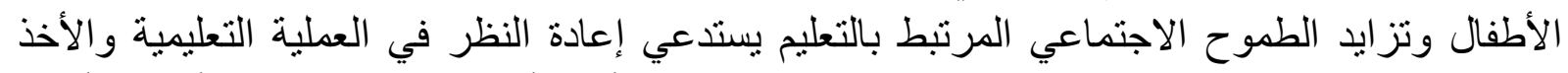

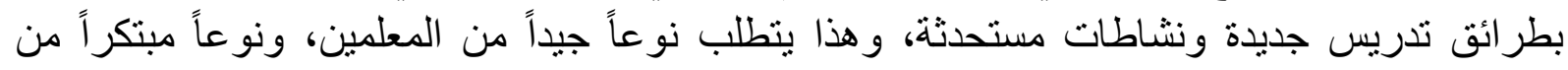

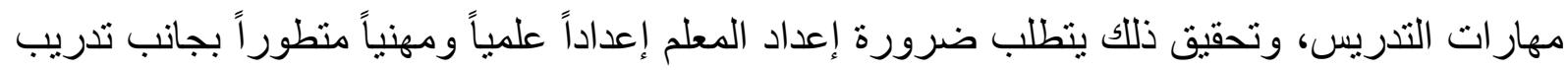

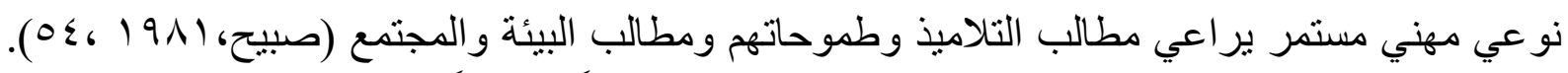

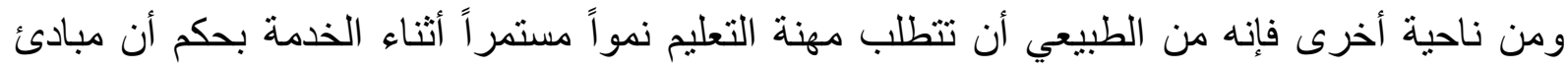

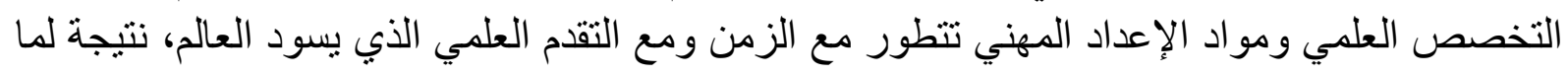
يحدث من مكتشفات حديثة تصحبها بروز حقائق جديدة ـ وقد انعكس كل ذللك على متطلبات مهنة التعليم

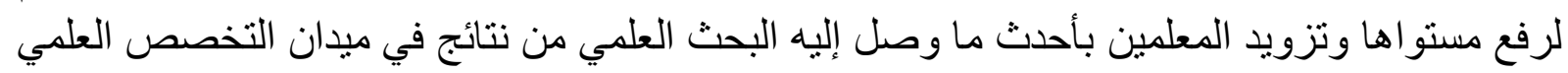

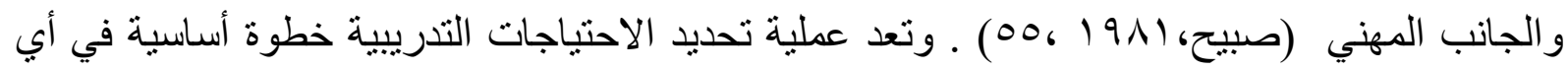

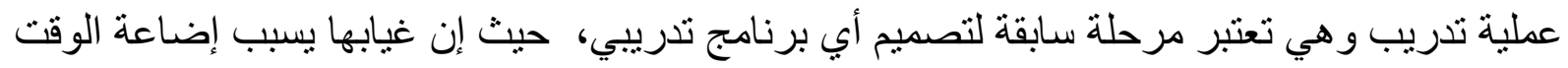
و المال (درة، الو9 99 م). ويتم خلال عملية تحديد الاحتياجات التدريبية تحليل عمل المعلم ومعرفة ولئ واجباته

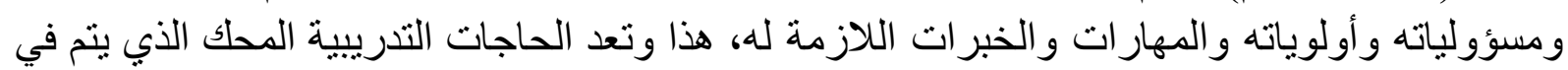

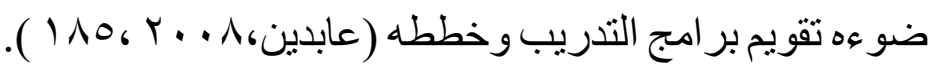

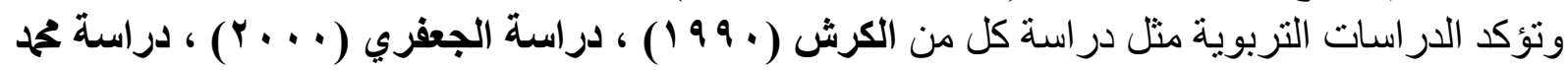

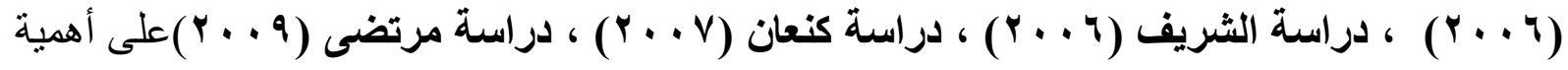




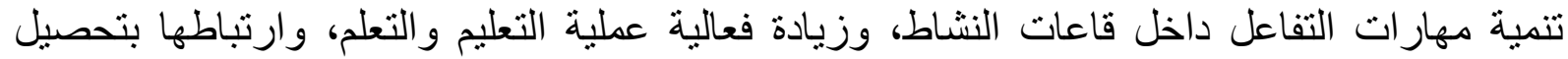

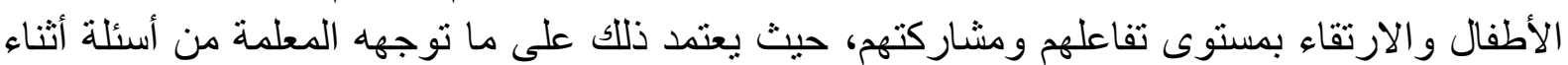
ممارسة الأطفال لأنشطة المنهج. وتعتبر النماذج الحديثة للتعليم/ التعلم بأن التعلم نشاط اجتماعي ييني فيه الأطفال معارفهم من خلال

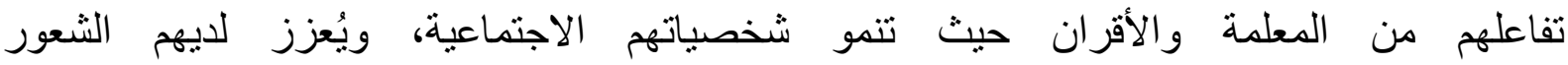
بالانتماء) (Maniago, 2006, p.2).

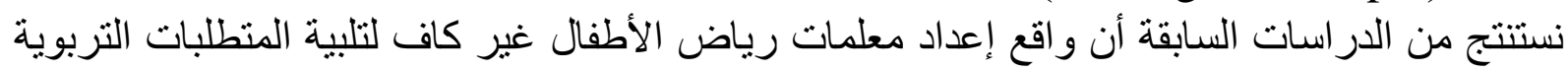

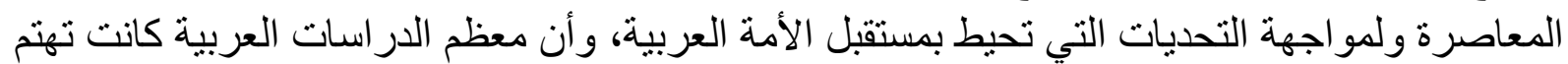

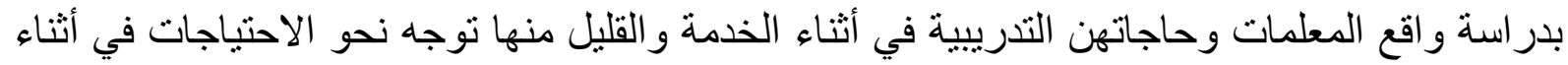

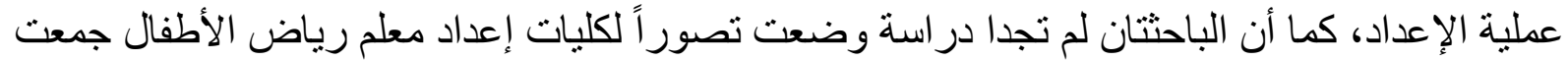
التوجه نحو الجودة ومدرسة المستقبل و التوجهات الأخلاقية الأدبية في عملية إعداد الإدل معلم رياض الإل الأطفال.

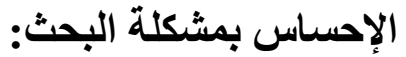
نبع الإحساس بمشكلة البحث الحالي مما يلي:

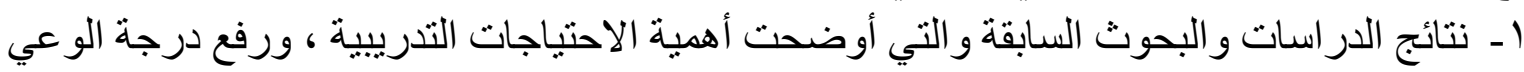

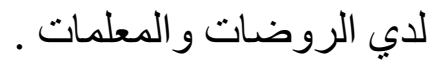
r ـ ما أثنارت إليه نتائج بعض الدر اسات و البحوث السابقة من عدم وعى معلمات الأطفال بأهمية التنمية

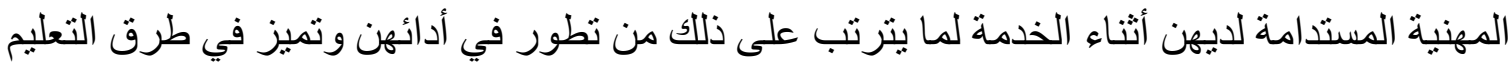

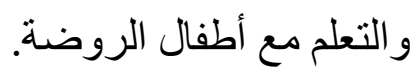

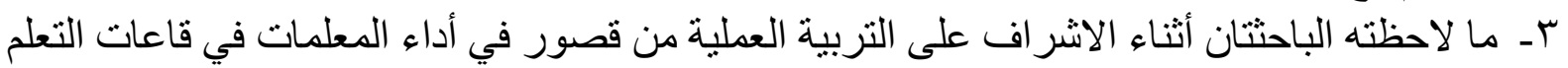

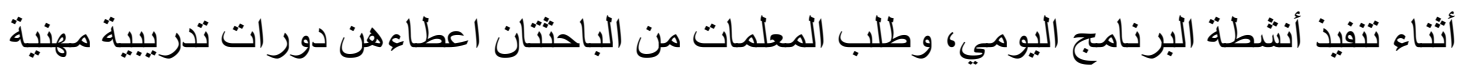

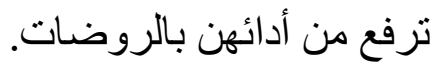

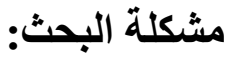

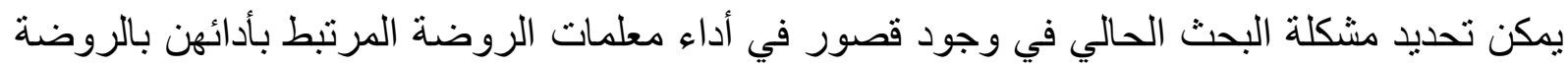

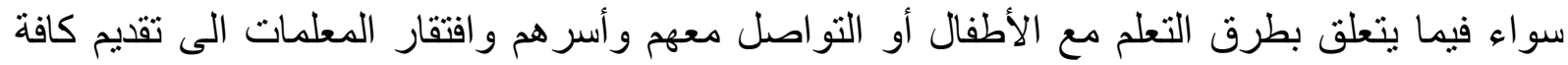

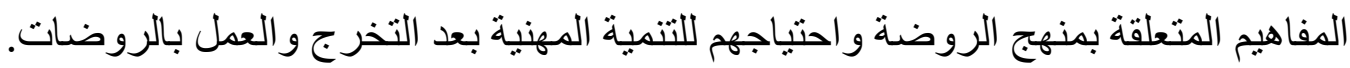

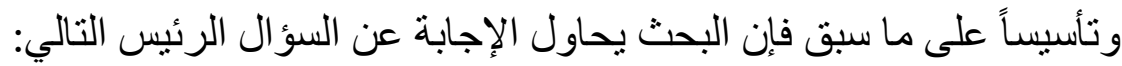

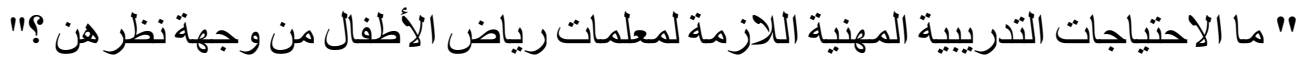
و الذي تتفرع منه الأسئلة الآتية : الآنية

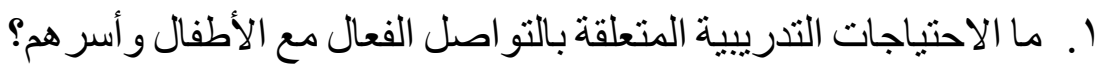

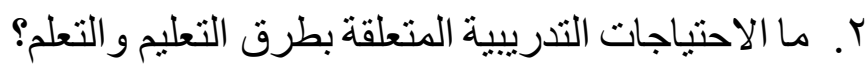

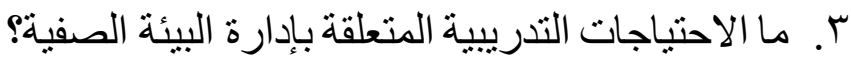

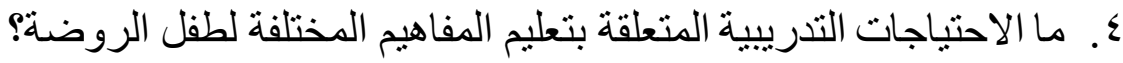

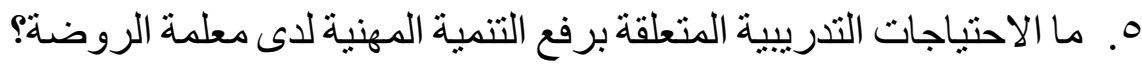

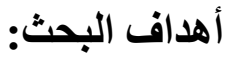

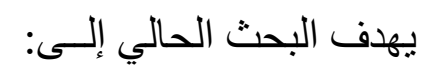

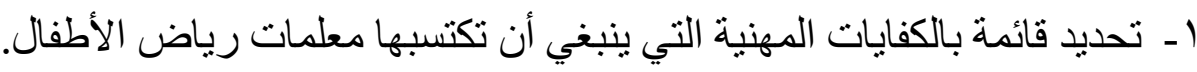

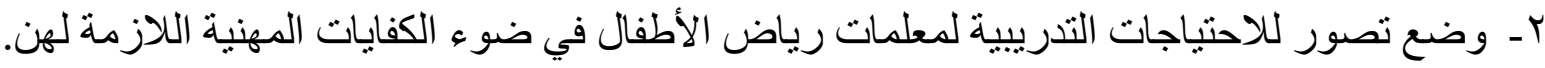


r- ك- توضيح مفهوم التتمية المهنية الثناملة لدى معلمات رياض الأطفال.

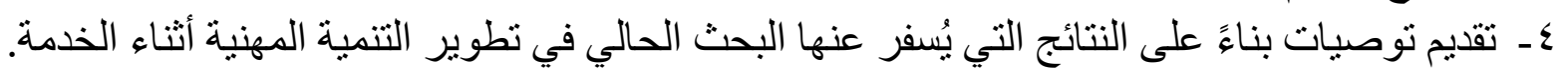

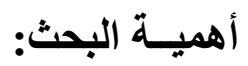

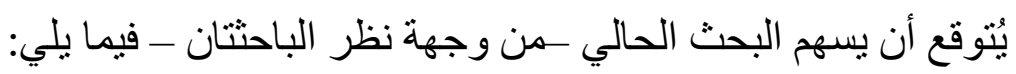

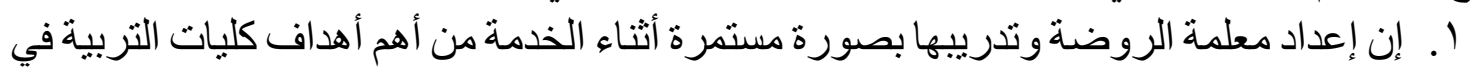

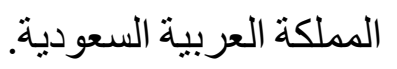

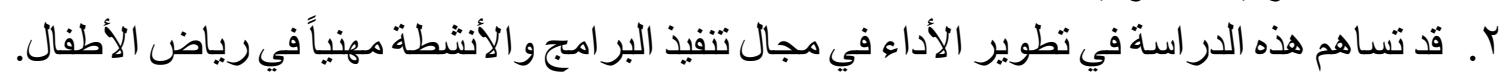

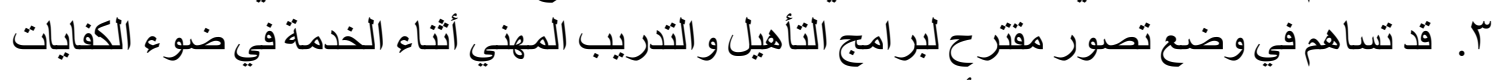

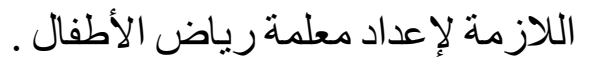

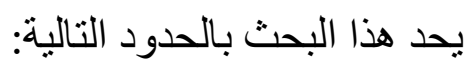

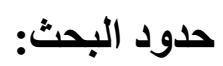

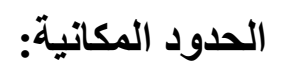

روضات القطاع الحكومي في محافظة الجبيل.

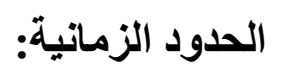

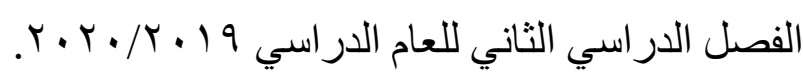

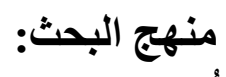
أستخدم المنهج الوصفي القائم على الدر اسة الميدانية باعتباره المنهج المناسب لهذا البحث.

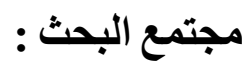
يتكون مجتمع البحث من ب ب معلمة من معلمات رياض الأطفال بعدد من روضات محافظة الجبيل.

\section{الاحتياجات التذريبية:}

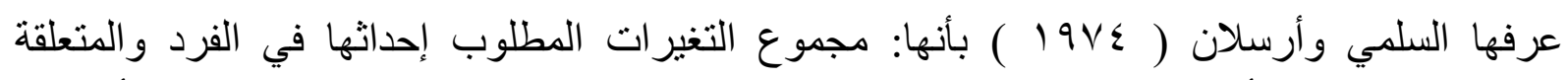

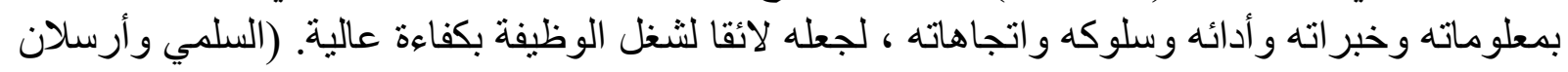

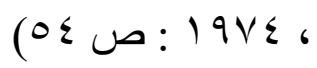

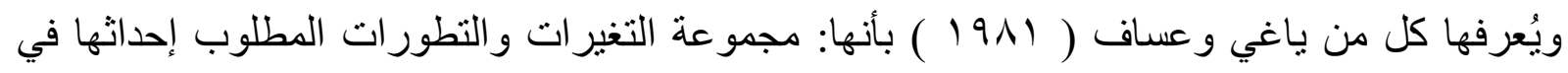

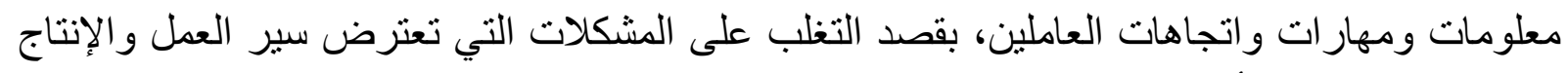

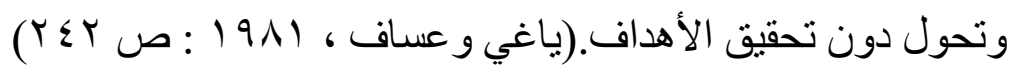

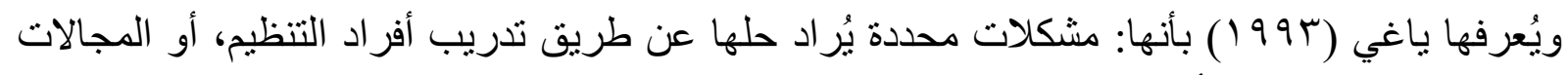

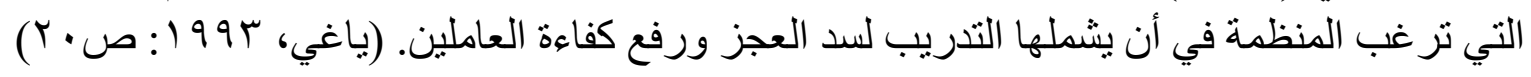
التعريف الاجرائي للاحتياجات التدريبية:

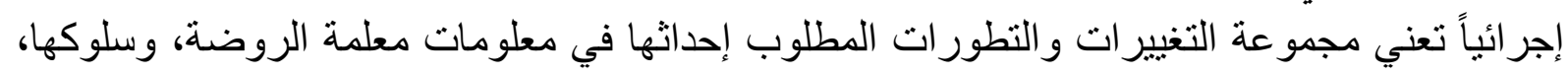

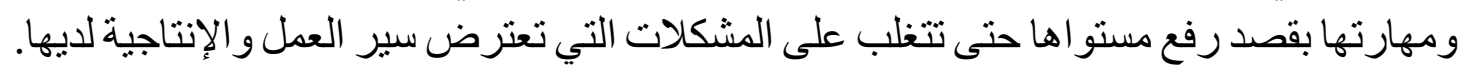
الإطــار النظري: اتجهت معظم بلدان العالم نحو إعداد معلم رياض الأطفال في مستوى جامعي، وقام الاتحاد الدولي للتربية

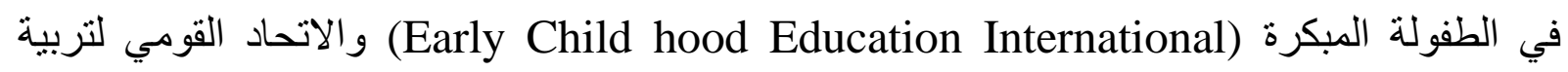
الطفولة المبكرة National Association for The education of Young Children 


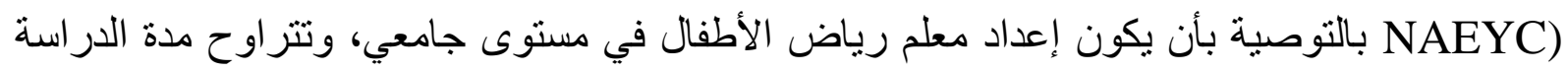

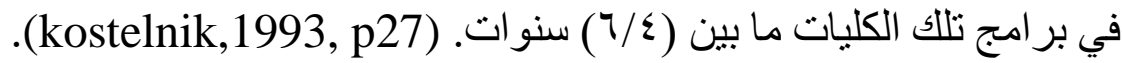

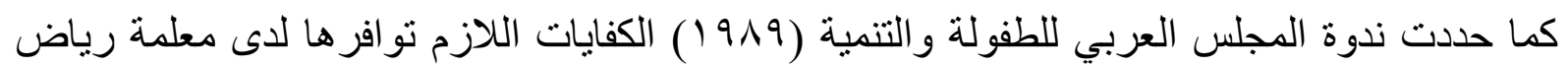

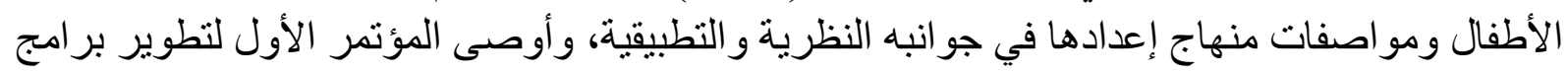

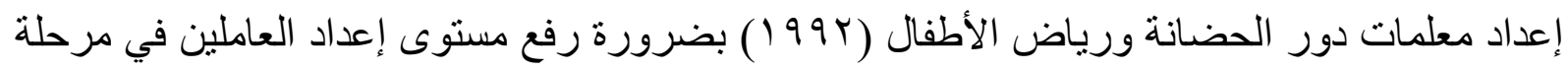

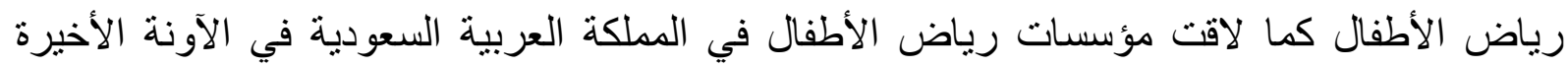

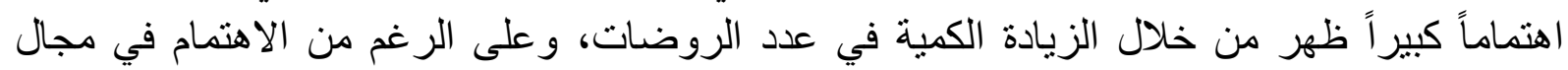

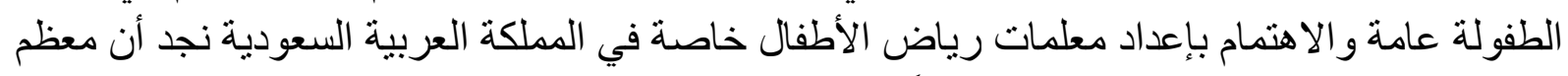

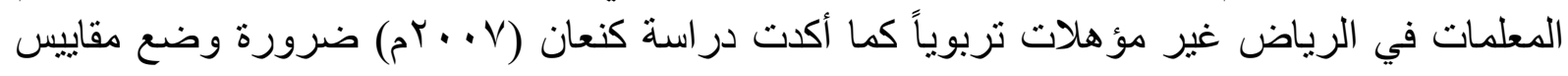

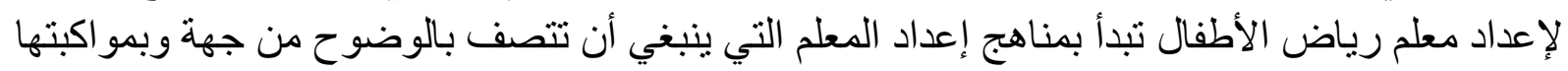

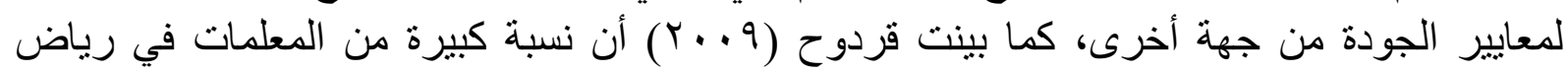

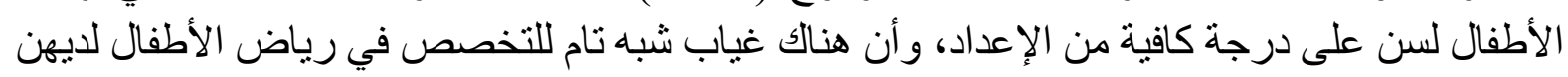

الاحتياجات التدريبية: الإل

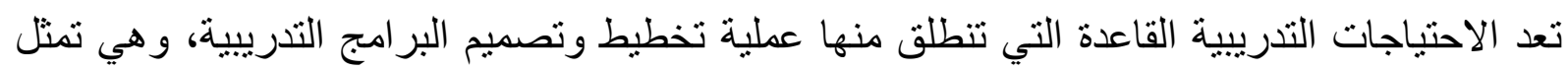

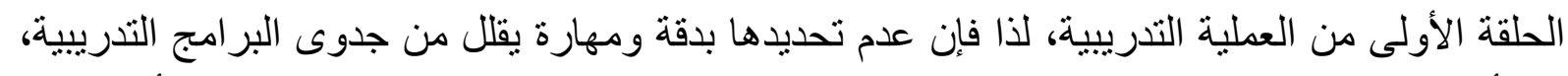

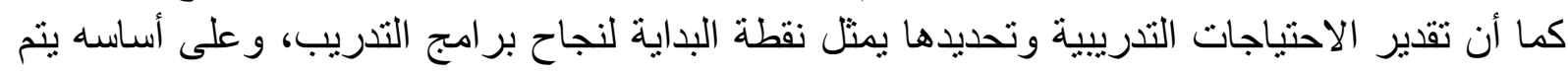
تقويم هذه البر امج التدريبية. مفهوم الاحتياجات التدريبية:

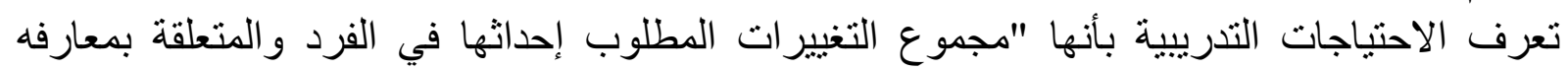

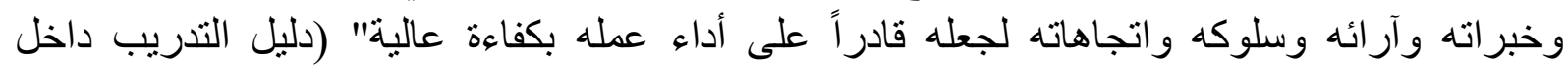

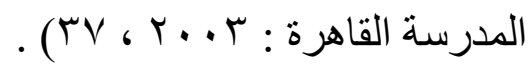
ويعرفها( Taibot

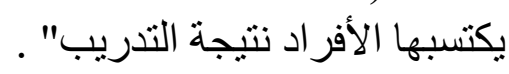
أهمية تحديد الاحتياجات التدريبية:

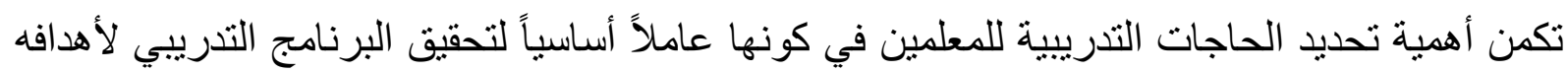

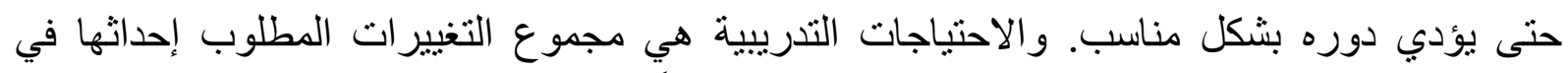

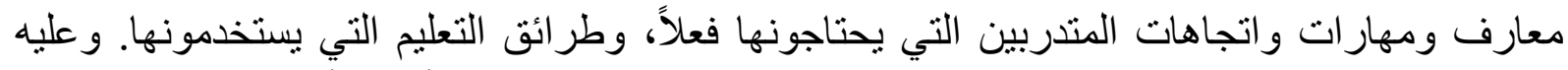

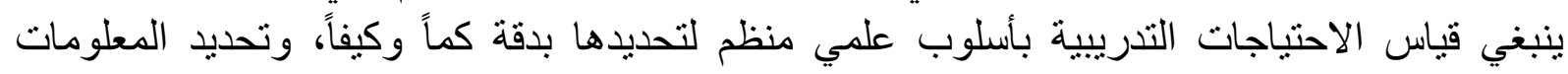

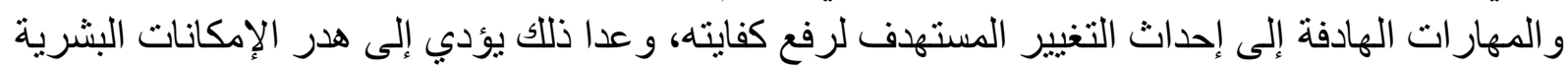

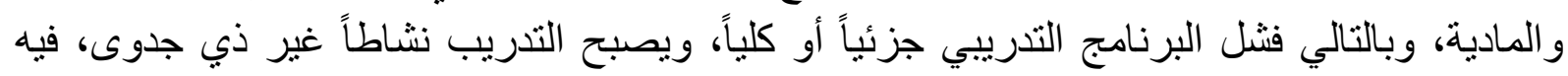

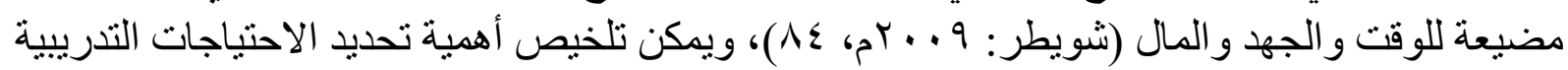

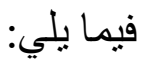

ا ا. تعد الاحتياجات التدريبية الأساس الذي يعتمد عليه أي نشاط تدريبي.

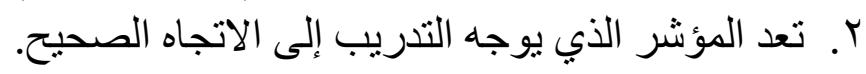

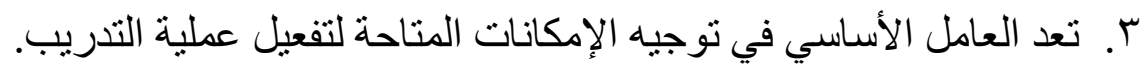

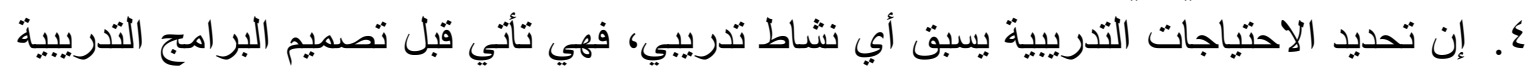
وتنفيذها. 
•. إن عدم التعرف على الاحتياجات التدريبية مسبقاً، يؤدي إلى ضياع الجهد و المال و الوقت المبذول في التدريب.

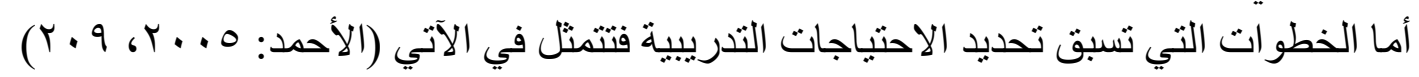
1. التعرف على مستويات الأداء الحالية للمتدربين.

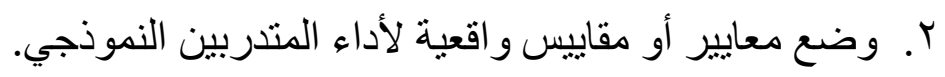

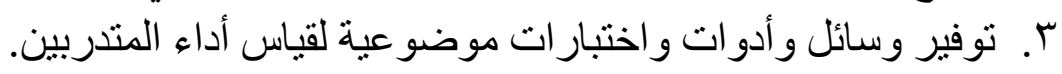

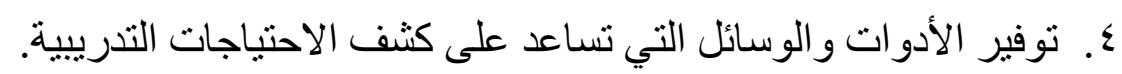

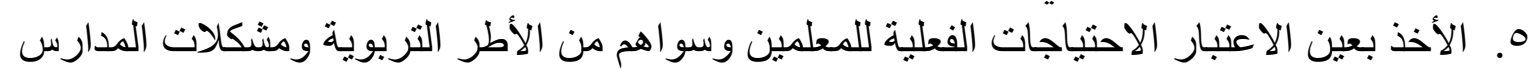

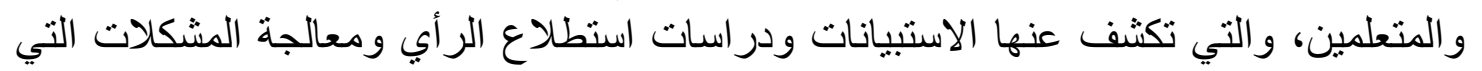

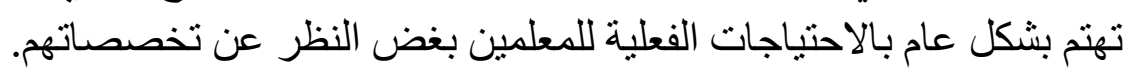

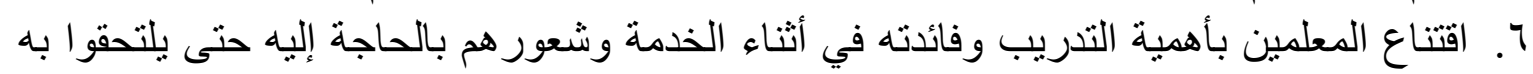

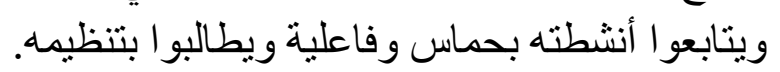

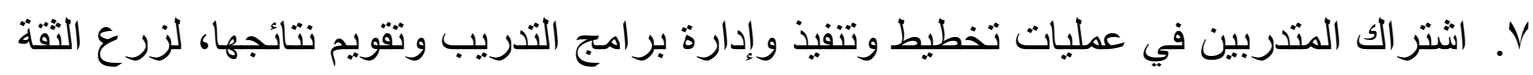

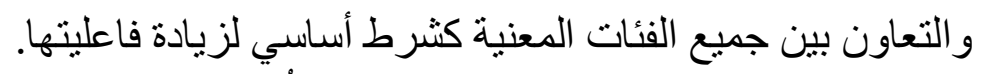

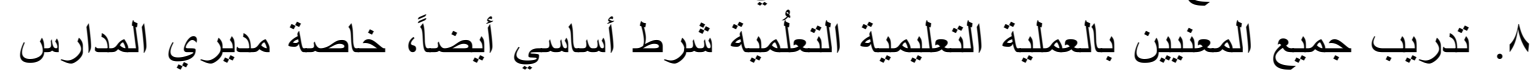

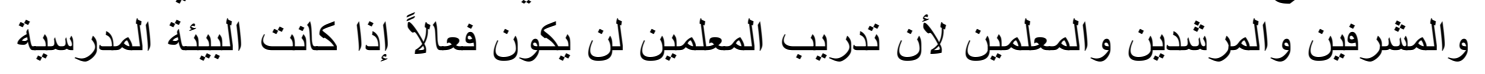
تقاوم التجديدات التربوية.

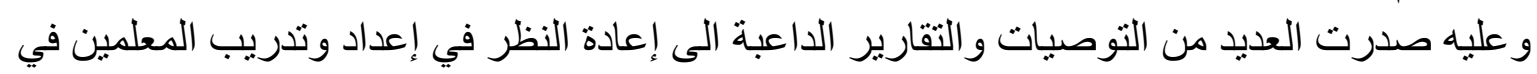

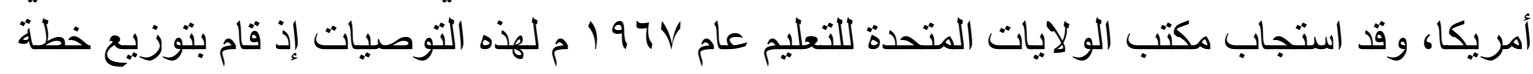

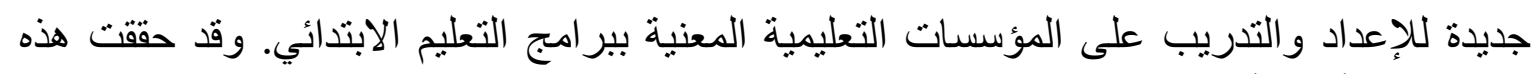

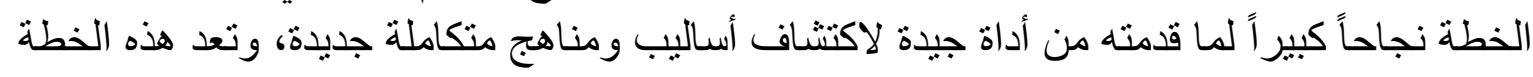

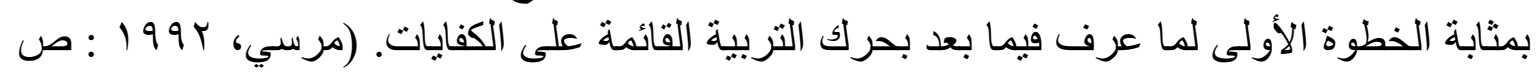

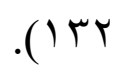

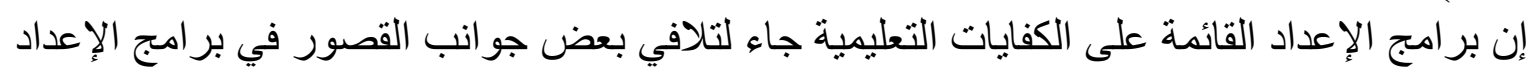

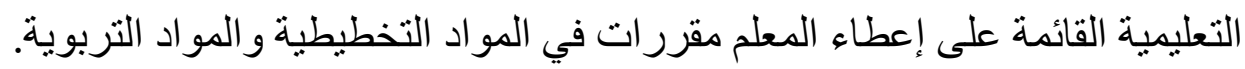

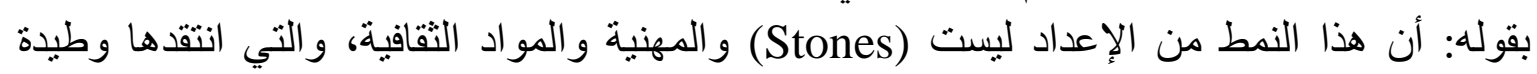

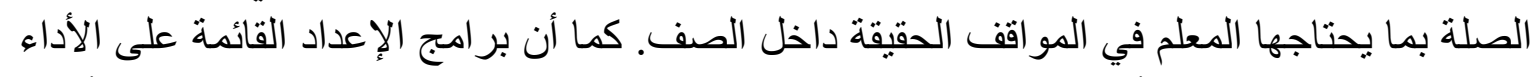

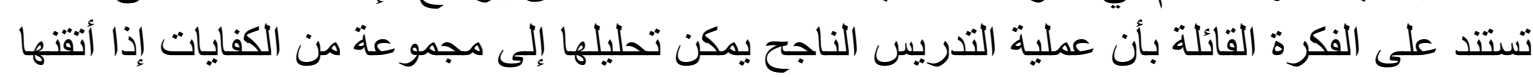

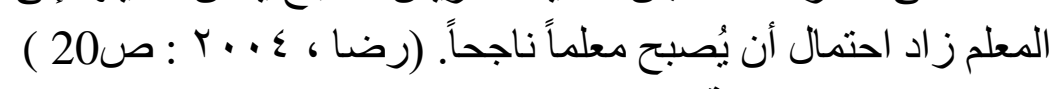
تحديد الاحتياجات التدريبية:

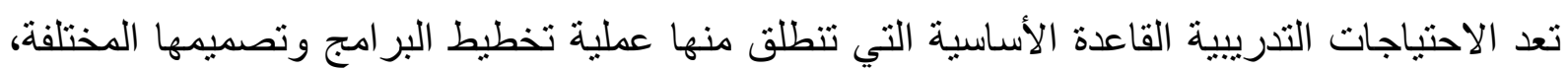

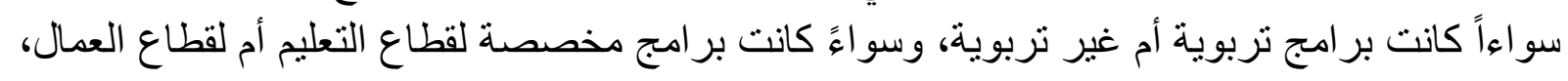

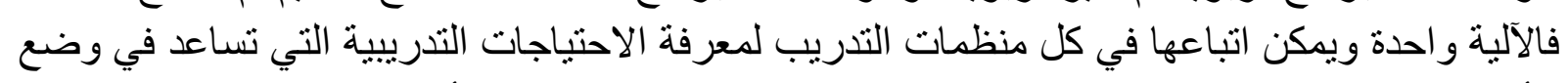

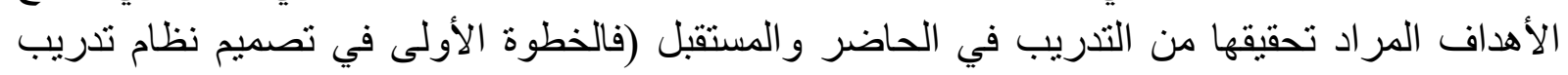

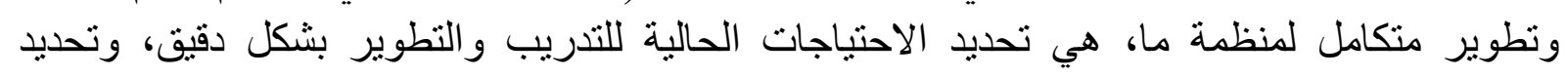

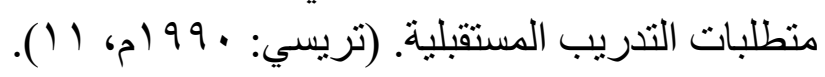




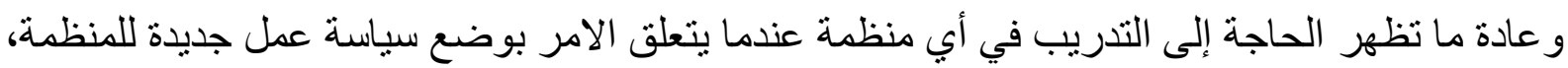

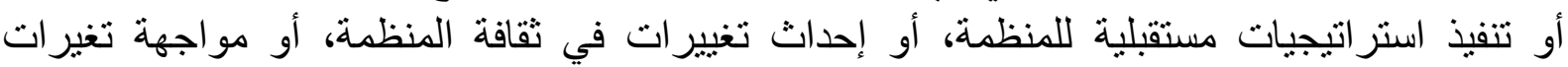

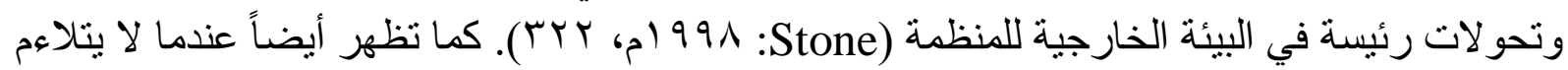

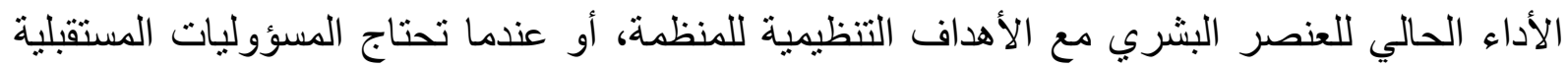

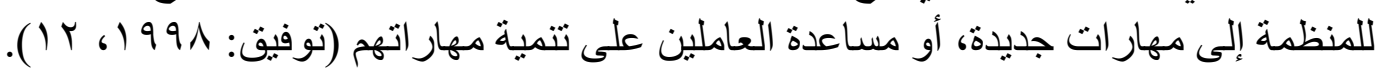

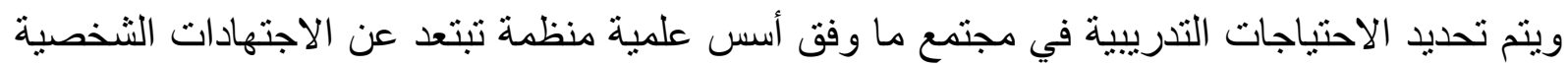

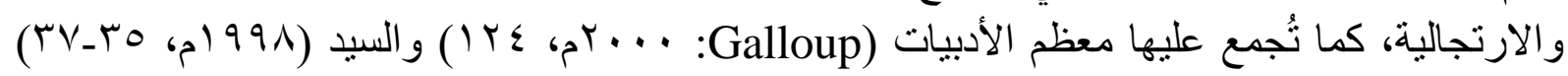

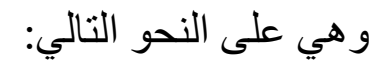
تحليل المنظمة (التنظيم):

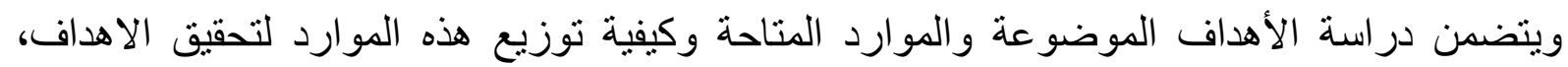

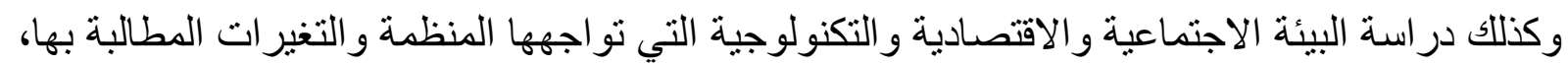

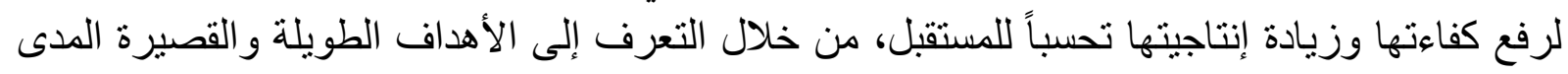

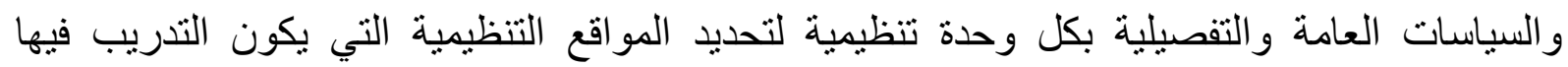

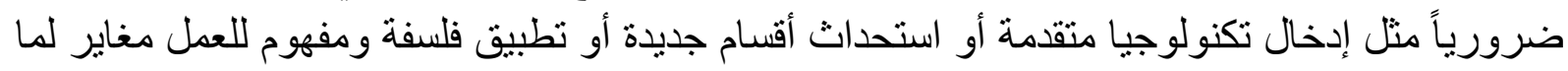
هو عليه في السابق. تحليل العمل (الوظيفة):

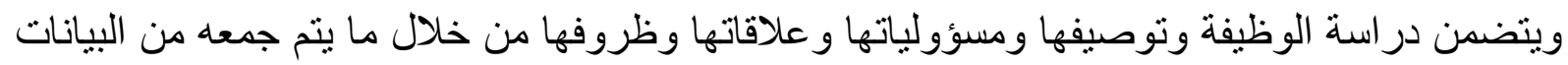

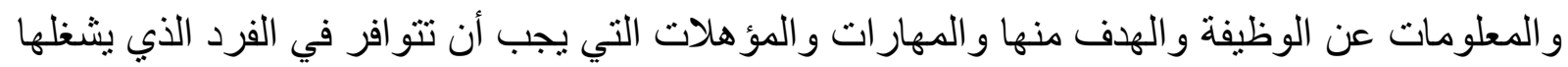

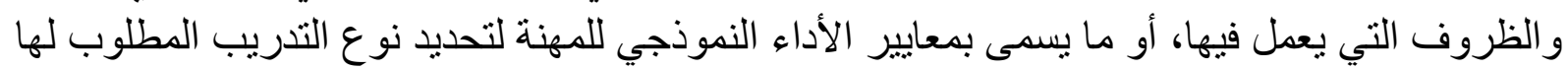

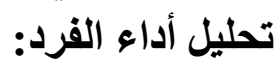

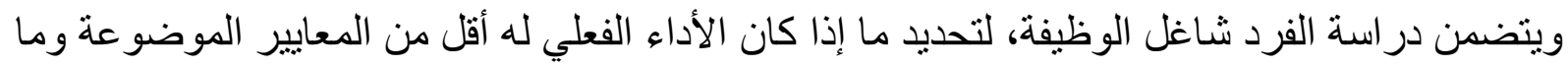

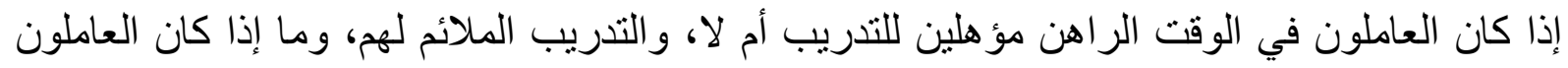

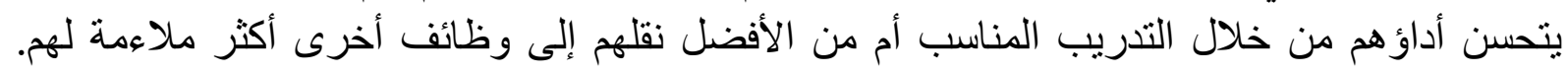

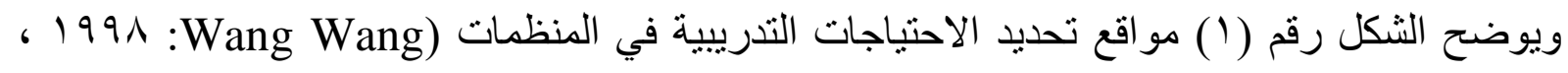
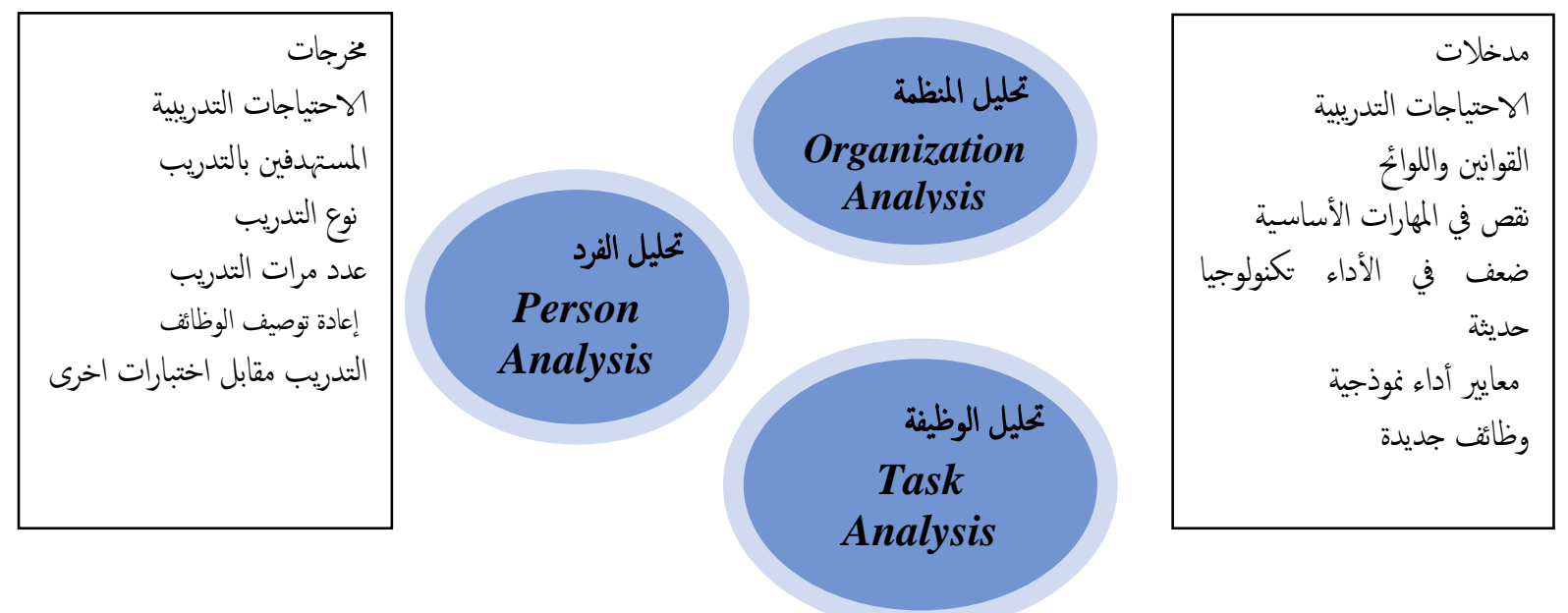

شكل رقم ( ) يوضح مواقع تحديد الاحتياجات التدريبية في المنظمات 
وتتعدد وتتنوع الأساليب و الوسائل التي يتم من خلالها التعرف إلى الاحتباجات التنريبية المختلفة والتي

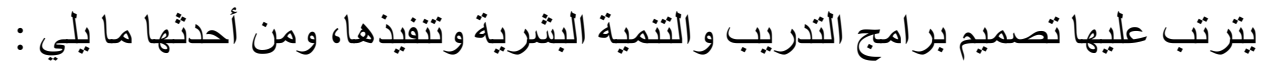

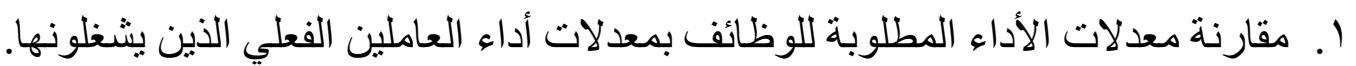

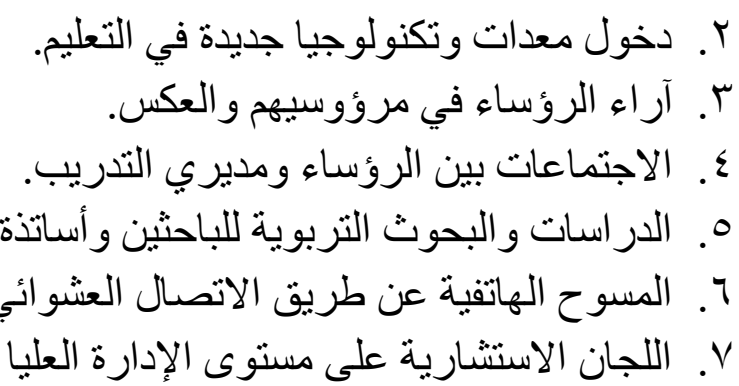

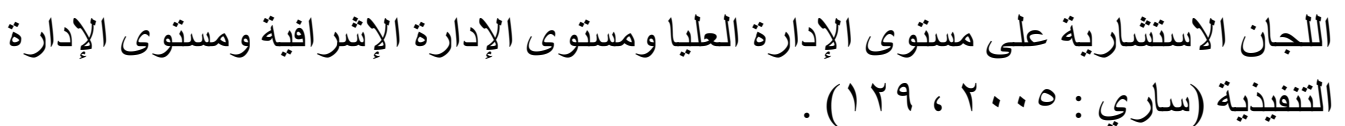

وفي ضوء ما تقدم فإن الرؤية المستقبلية لتحديد الاحتياجات التدريبية تكون عملية مستمرة وشاملة

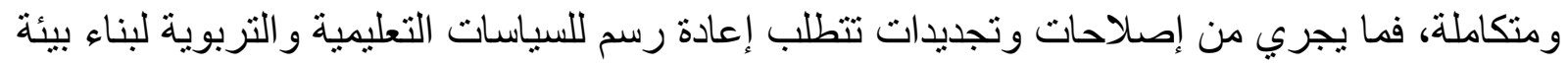

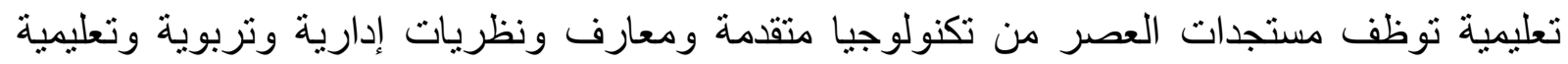

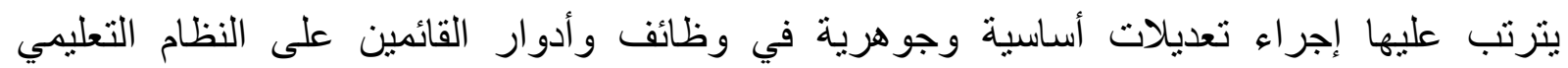

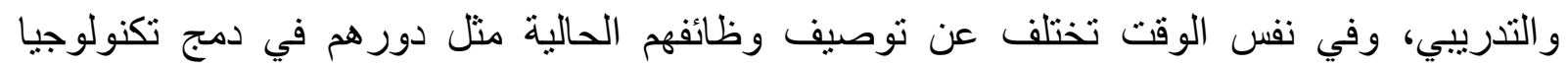

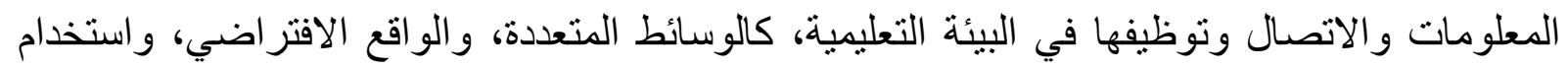

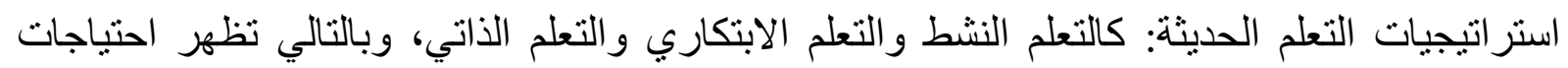

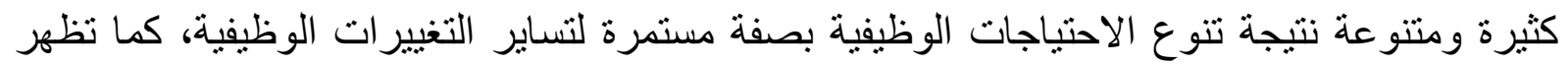

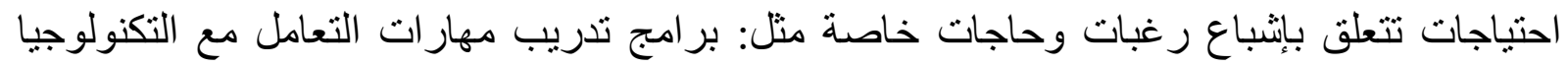

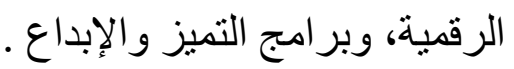

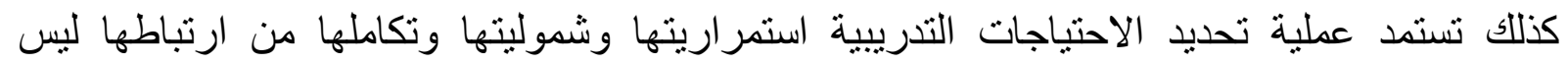

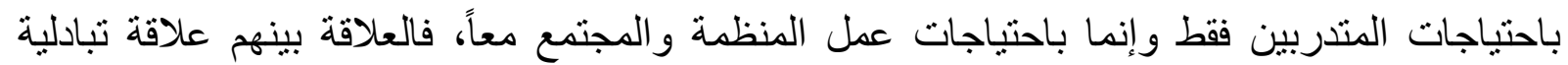

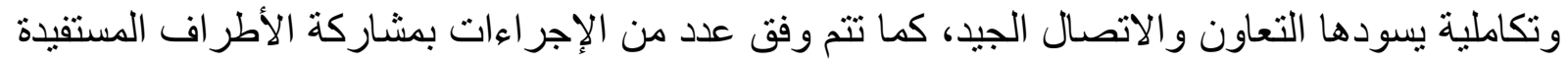

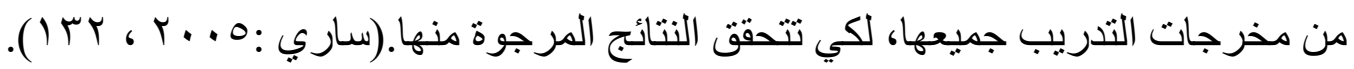
منهج البحث وأدواته: من النّات

اعتمد البحث على الينهج الوصني الونهي التحليلي لوصف حاجات معلمات رياض الأطفال ومن ثم تحليلها.

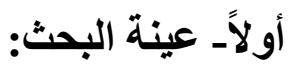
تم اختبار معلمات رياض الأطفال بطريقة عشو ائية عدة روضات حكومية في محافظة الجبيل التابعة

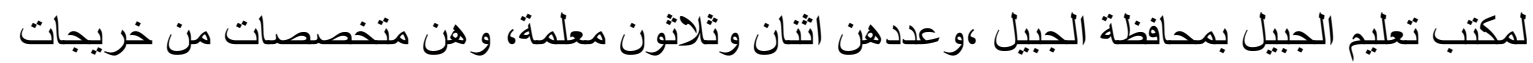

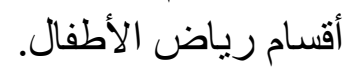
توزيع أفر اد مجتمع البحث طبقاً للموقع و العدد:

\begin{tabular}{|c|c|c|}
\hline عدد المعثمات & اسم الروضة & p \\
\hline A معلمات & الروضة الحكومية الأولى & 1 \\
\hline r معلمات & الروضة الحكومية الثانية & $\bar{Y}$ \\
\hline 9 معلمات & الروضة الحكومية الثالثة & $r$ \\
\hline rا معلمة & الروضة الحكومية الرابعة & $\varepsilon$ \\
\hline
\end{tabular}




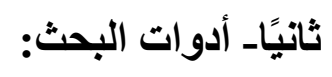

لغرض تحديد الاحتباجات التنريبية لدى معلمات رياض الإن الأطفال، قامت الباحثتان بإعداد استبانة في

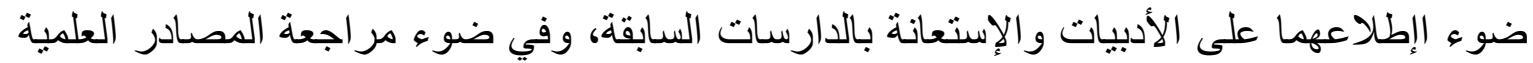

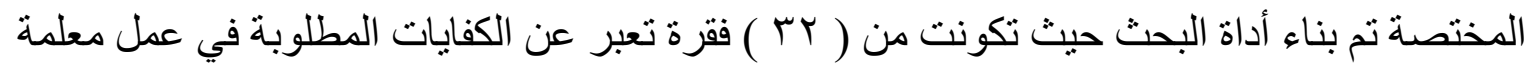

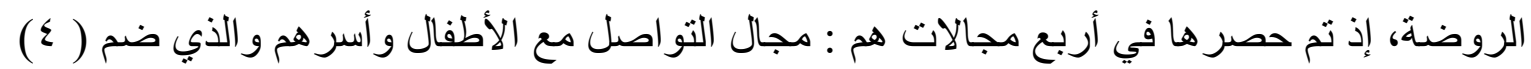

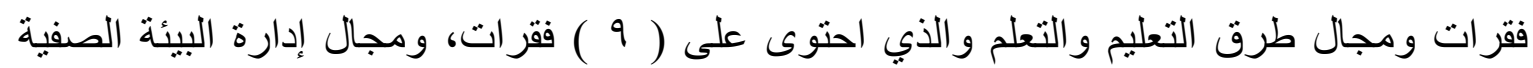

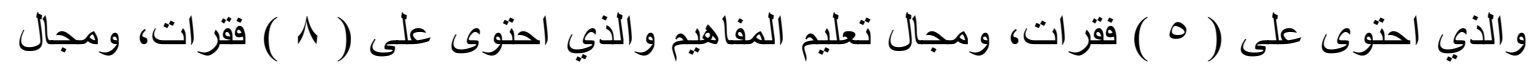

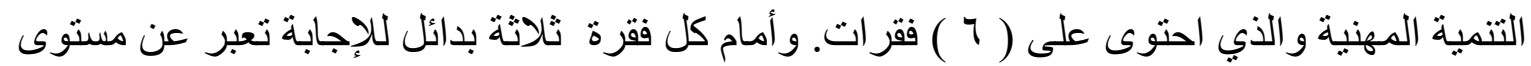

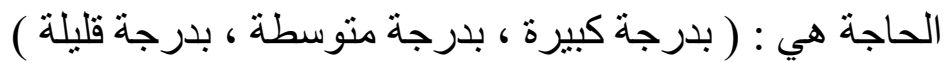

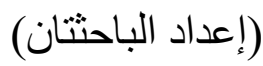

$$
\text { صدق وثبات أدوات الاراسة: }
$$

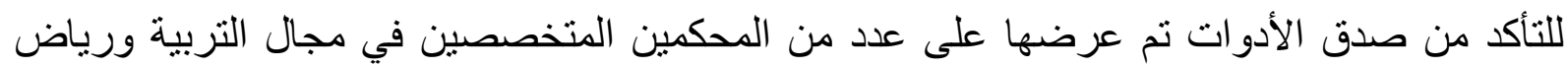

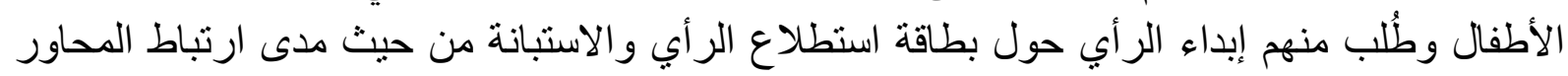

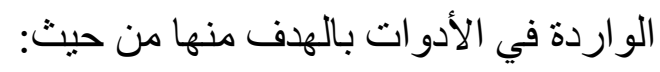

مدى ارتباط كل مفردة بالمحور الذي تنتمي إليه.

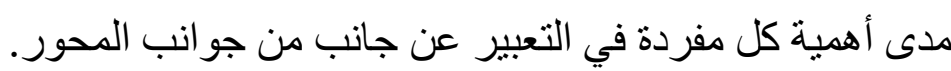

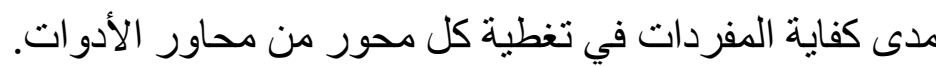

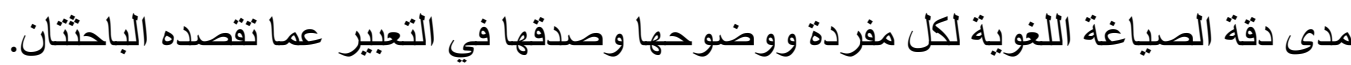

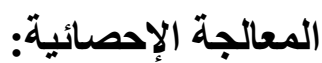

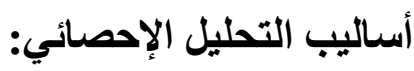

تم تفريغ البيانات عن طريق البرائنائمج الإحصائي المعروف برنامج الحزم الإحصائية للعلوم

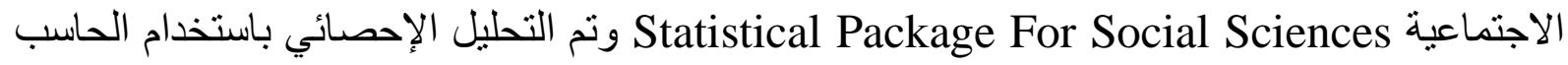

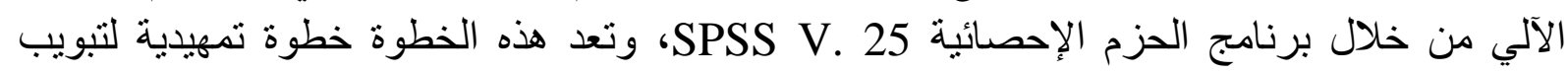

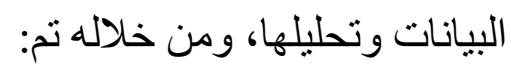
اـ اختبار الثبات من خلال معامل ألفا كرونباخ Alpha Cronbach's لاختبار ثبات متغيرات

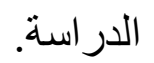
r- اختبار صدق الإتساق الداخلي من خلال معامل إرتباط بيرسون بين أبعاد الدراسة وإجمالي الاستمارة.

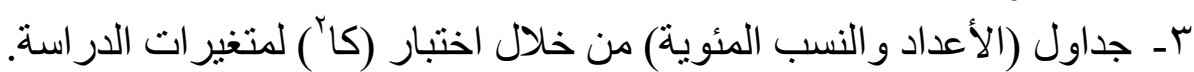

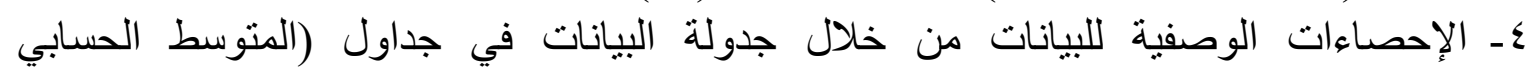
و الإنحر اف المعياري و الوزن النسبي المئوي) لمتغير الئنات الدراسة. 
ثبات وصدق أداة الاراسة:

جدول ( ) ) ثبات استمارة الاحتياجات التدريبية لمعلمة الروضة

\begin{tabular}{|c|c|c|}
\hline قألفاة & عدد العبارات & 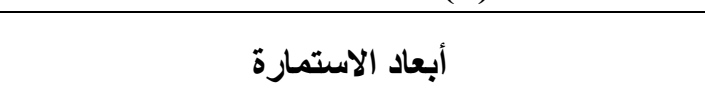 \\
\hline .019 & $\varepsilon$ & المجال الأول: التواصل الفعال مع الأطفال و أسرهم \\
\hline$\because \wedge \varepsilon \vee$ & 9 & المجال الثاني: طرق التعليم والتعلم \\
\hline .771 & 0 & المجال الثالث: إدارة البيئة الصفية \\
\hline$\because \vee \vee \mu$ & $\wedge$ & المجال الرابع: تعليم المفاهيم المختلفة لطقل الروضة \\
\hline$\because \mathrm{VOV}$ & 7 & المجال الخامس: التنمية المهنية لمعلمة الروضة \\
\hline $.9 \pi$ & rt & إجمالي استمارة الاحتياجات التدريبية لمعلمة الروضة \\
\hline
\end{tabular}

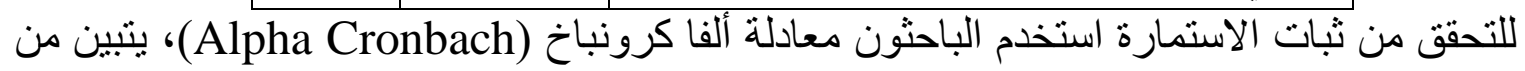

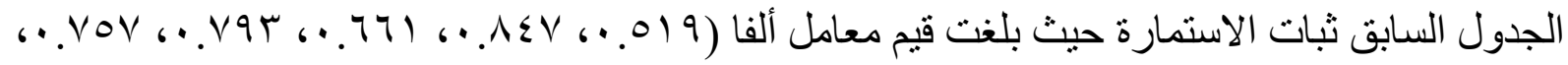
بrq. • ) لكل من (المجال الأول: التواصل الفعال مع الأطفال وأسرهم، المجال الثاني: طرق التعليم

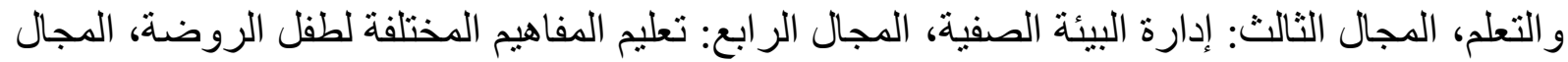

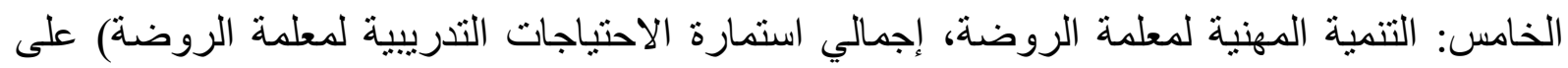

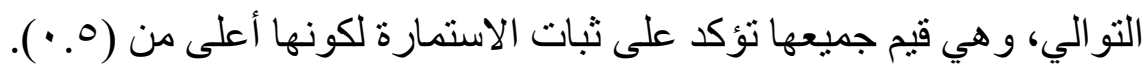

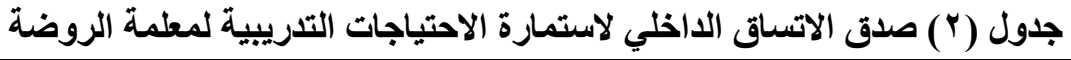

\begin{tabular}{|c|c|c|}
\hline الدلالة المعنوية & معامل ارتباط بيرسون & أبعاد الاستمارة \\
\hline$\because \cdots 1$ & 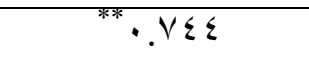 & المجال الأول: التواصل الفعال مع الأطفال وأسرهم \\
\hline$\because \cdots 1$ & $* * \cdot 9 \cdot V$ & المجال الثاني: طرق التعليم والتعلم \\
\hline$\because \cdots 1$ & $\because \wedge 99$ & المجال الثالث: إدارة البيئة الصفية \\
\hline$\because \cdots 1$ & $\cdot .919$ & المجال الرابع: تعليم المفاهيم المختلفة لطفل الروضة \\
\hline$\because \cdots 1$ & $\cdot \wedge \wedge \vee$ & المجال الخامس: التنمية المهنية لمعلمة الروضة \\
\hline
\end{tabular}

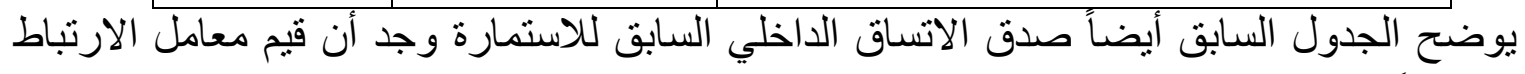
دالة إحصائياً عند مستوى معنوية (0. . • )، مما يؤكد على صدق الاتساق الداخلي لكل من (المجال الأول:

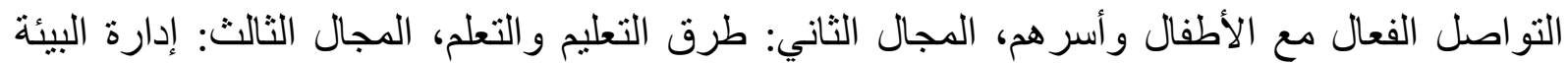

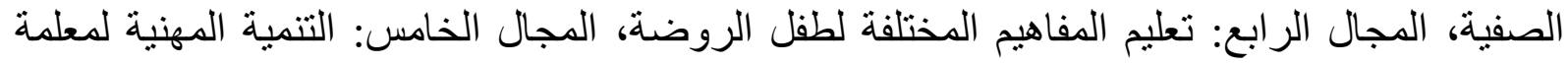

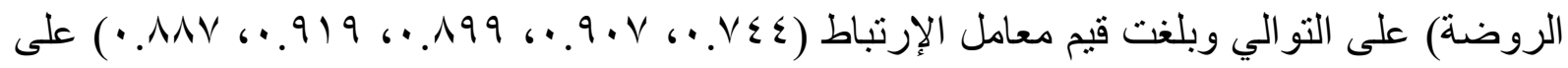

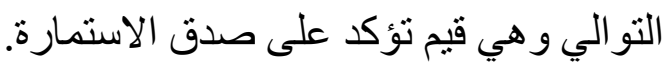
جدول (ّ) ثبات بالتجزئة النصفية لاستمارة الاحتياجات التدريبية لمعلمة الروضة

\begin{tabular}{|c|c|c|c|}
\hline معامل الإرتباط المصحح & الدلالة المعنوية & معامل ارتباط بيرسون & المتغير ات \\
\hline$\cdot .9 \wedge r$ & $\because \cdots 1$ & $\cdot .970$ & العبارات الفردية \\
\hline .911 & $\because \cdots 1$ & ${ }^{* *} \cdot .97 r$ & العبارات الزوجية \\
\hline
\end{tabular}

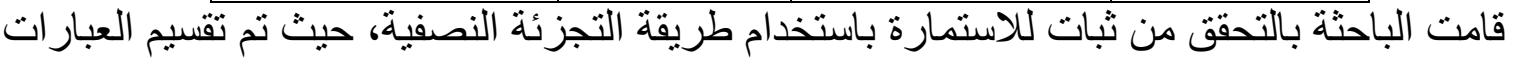

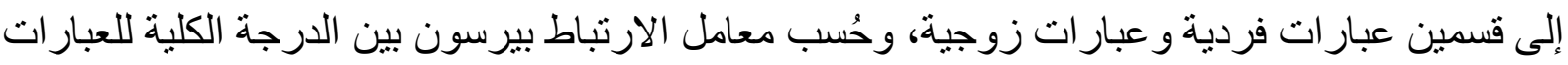

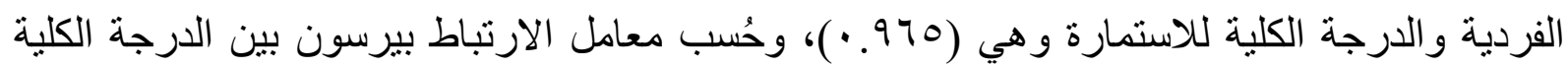

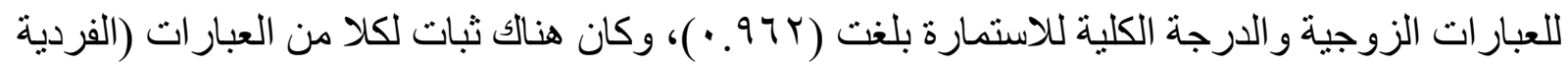
و الزوجية) حيث كانت قيمتا معامل الارنباط دالة معنويًا عند مستوى (0. . •)، وبلغ معامل الارتباط وناط 


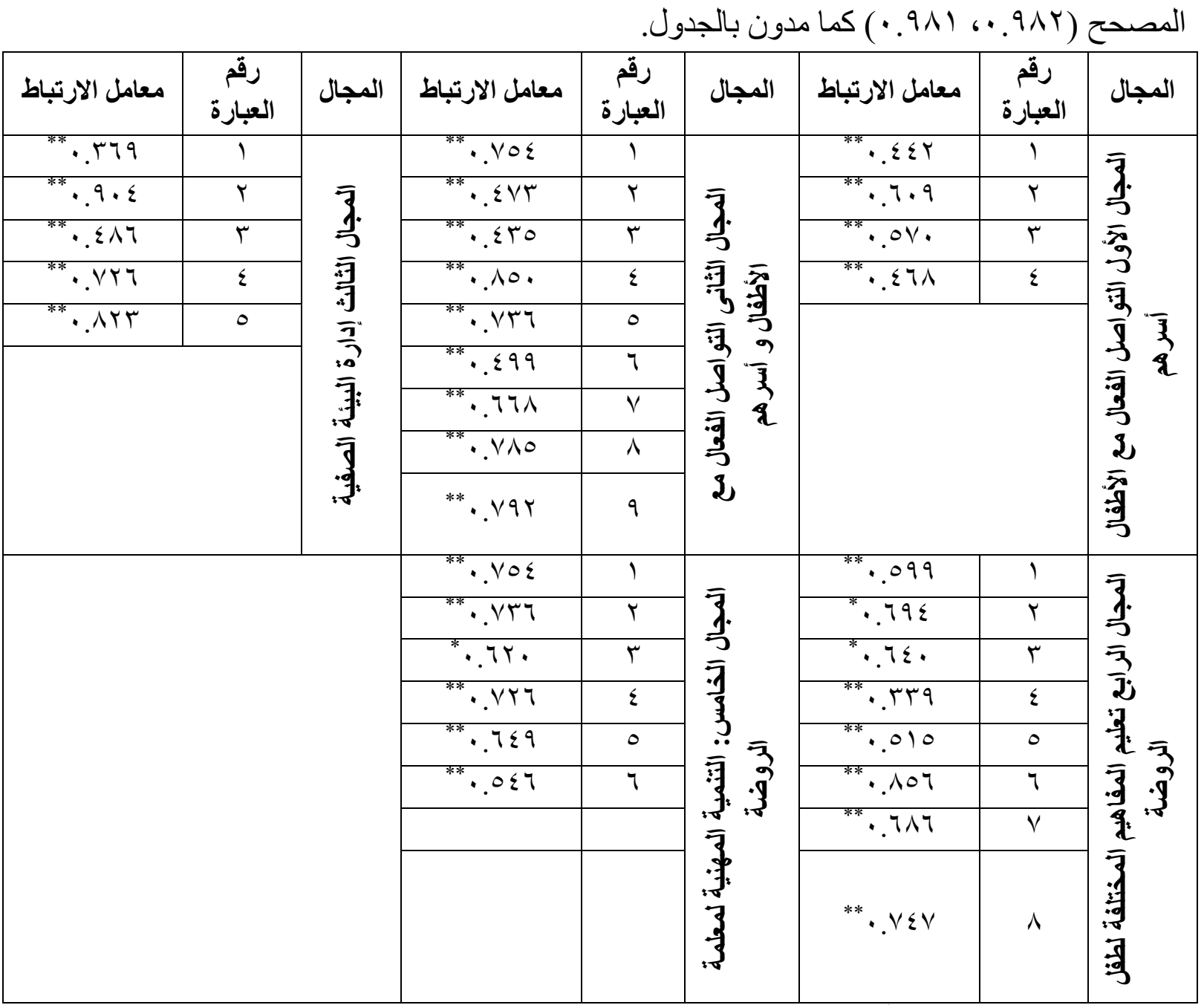

يتضح من الجدول السابق أن جميع قيم معاملات الارتباط دالة إحصائيًا عند مستوى دلالة (0. . •) لعبار ات استمارة الاحتياجات التدريبية لمعلمة الروضة مما يؤكد صدق الاتساق الداخلي لعبارات استمارة الاحتياجات التنديبية لمعلمة

\section{التمقق هن صحة تساؤلات الدراسية:}

التساؤل الأول: هل الاهتياجات التدريبية المتعلقة بالتواصل الفعال مع الأطفال وأسرهم؟

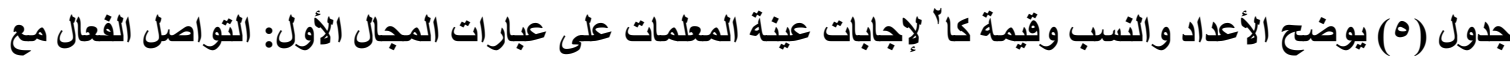
الأطفال وأسرهم

\begin{tabular}{|c|c|c|c|c|c|c|c|c|}
\hline \multirow{2}{*}{ المعنو الالة } & \multirow{2}{*}{ كا' } & \multicolumn{2}{|c|}{ كبيزة } & \multicolumn{2}{|c|}{ متوسطة } & \multicolumn{2}{|c|}{ ضعيفة } & \multirow{2}{*}{ 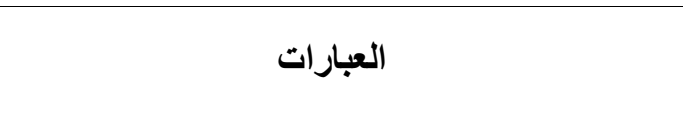 } \\
\hline & & $\%$ & ك & $\%$ & ك5 & $\%$ & ك5 & \\
\hline$\cdot r$ & 1.09 & $0 \wedge . \wedge$ & $r \cdot$ & $\leqslant 1 . r$ & $1 \varepsilon$ & $\cdot$ & . & 1 الـ معرفة حاجات وخصائص النمو الثامل لطفل \\
\hline$\because 9$ & r.9ะ1 & $7 \varepsilon . V$ & rr & ro.r & IT & - & $\cdot$ & ץ.طرق التواصل الجيد مع الأطفال وأسرهم \\
\hline .0 & E.TTO & $7 V .7$ & $r T$ & TY. & 11 & - & • & 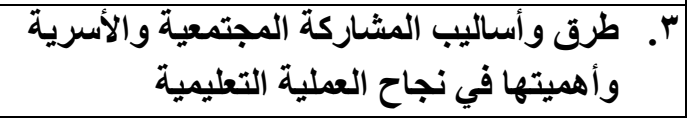 \\
\hline$\because \cdots 1$ & $01 . Y T 0$ & 91.4 & r & 0.9 & r & r.9 & 1 & ؛ ؛ أساليب للتعامل مع الطقل وتوجيه سلوكه \\
\hline
\end{tabular}

يوضح الجدول السابق إجابات عينة المعلمات على عبارات المجال الأول: التواصل الفعال مع الأطفال وأسرهم 
لا نوجد فروق بين إجابات العينة للتساؤل الأول (معرفة حاجات وخصائص النمو الثامل لطفل

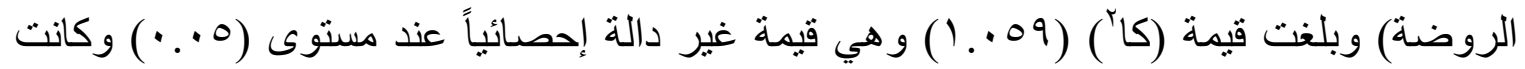

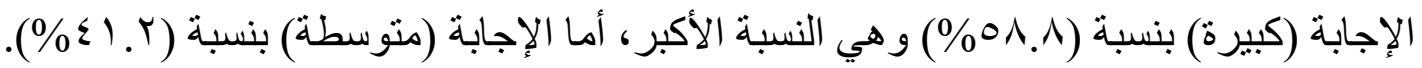

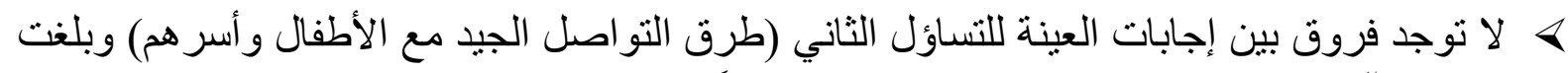

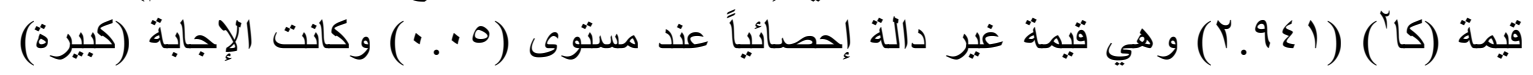

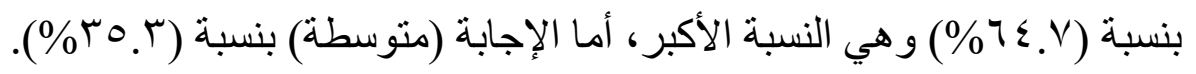

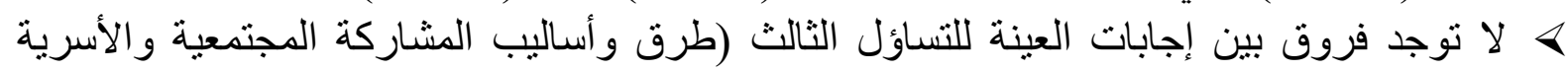

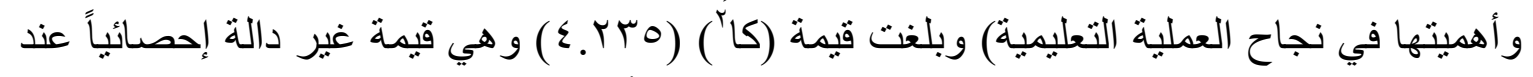

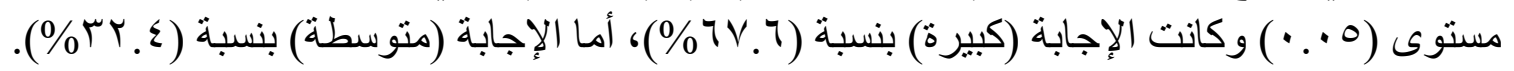

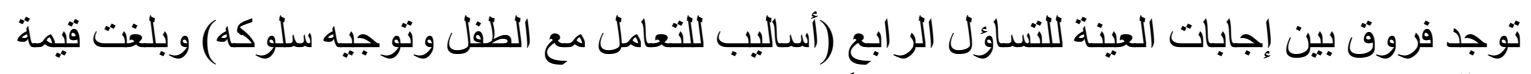

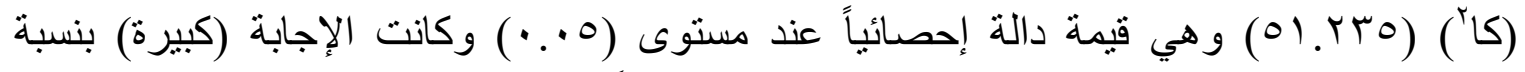

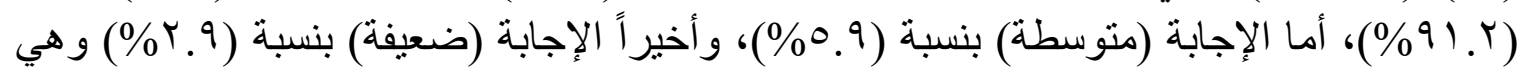

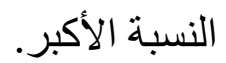

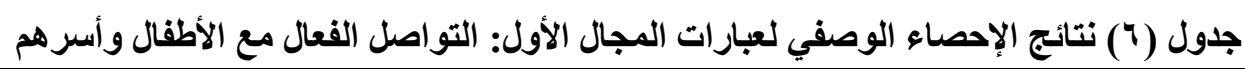

\begin{tabular}{|c|c|c|c|c|}
\hline الترتيب & اللنسبي & المعياري & الحسابي & العبارات \\
\hline$\varepsilon$ & A५.r & $\because 0$ & 5.09 & 1. معرفة حاجات وخصائص النمو الثامل لطفل الروضة \\
\hline r & $\Lambda \wedge . r$ & $\cdot . \leqslant 9$ & Y.70 & 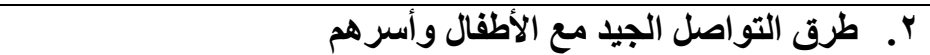 \\
\hline r & 19.r & $\cdot \Omega \wedge$ & r. & "ا. طرق وأساليب المشاركة المجتمعية والأسرية وأهميتها في نجاح \\
\hline 1 & 97. &.$\Omega 1$ & r.A1 & ؛.أساليب للتعامل مع الطفل وتوجيه سلوكه \\
\hline الثاني & $9 \cdot . \cdot$ & 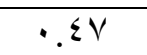 & r.v. & المجال الأول: التواصل الفعال مع الأطفال وأسر هم \\
\hline
\end{tabular}

يتبين من الجدول السابق أن متوسط الدرجة الكلية الدجال الأول: التواصل الفعال مع الأطفال

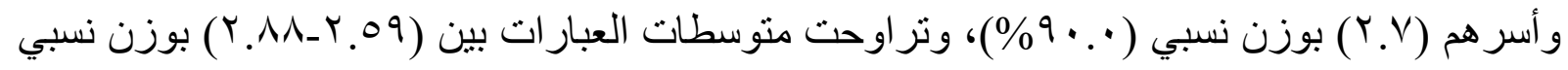

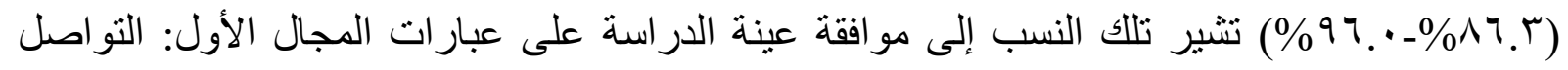
الفعال مع الأطفال و أسر هم وكان ترتيب أهمية المجال بالنسبة لمجالات الاستمارة الثاني. 
التساؤل الثانيى: ما الاهتياجات التندريبية المتعلقة بطروق التعليم والتعلم؟

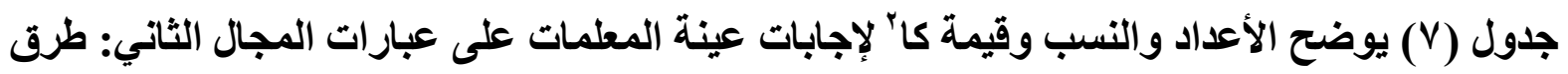
التعليم والتعلم

\begin{tabular}{|c|c|c|c|c|c|c|c|c|}
\hline \multirow{2}{*}{ المغنوية } & \multirow{2}{*}{ كاr } & \multicolumn{2}{|c|}{ كبيرة } & \multicolumn{2}{|c|}{ متوسطة } & \multicolumn{2}{|c|}{ ضعيفة } & \multirow{2}{*}{ 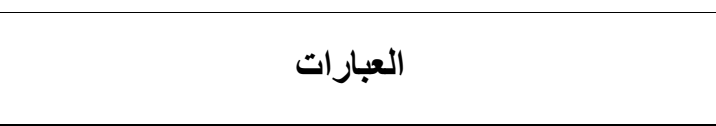 } \\
\hline & & $\%$ & ك & $\%$ & ك & $\%$ & ك5 & \\
\hline$\because 0$ & $1 \cdot .7 \leq V$ & $0 \wedge . \wedge$ & $r \cdot$ & Y..० & 9 & $1 \leqslant . V$ & 0 & 1. قياس تحققة الأهداف التعليمية وأنواعها وأساليب \\
\hline$\because \cdots 1$ & $r \cdot .1 \vee 7$ & $7 \vee .7$ & rt & Y५.0 & 9 & 0.9 & r & 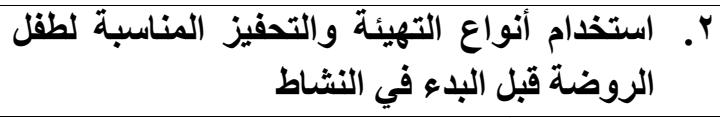 \\
\hline$\cdot r$ & 1.09 & $0 \wedge . \wedge$ & $r \cdot$ & $\varepsilon 1 . Y$ & $1 \leq$ & · & . & r. التخطيط للأنشطة في ضوء الأهداف التعليمية \\
\hline 1 & 11.11 & 00.9 & 19 & rᄉ.r & $1 T$ & 0.9 & $r$ & ؛. ـ مهارات توظيف التكنولوجيا في عملية التريس \\
\hline$\cdot r$ & 1.09 & $0 \wedge . \wedge$ & r. & $\varepsilon 1 . Y$ & $1 \leq$ & . & $\cdot$ & •. الاستراتيجيات الحديثة والفعالة لتدريس الأطفال \\
\hline$\because \cdots$ & V.orq & $\mathrm{Vr} . \mathrm{O}$ & ro & Y. & 9 & . & • & 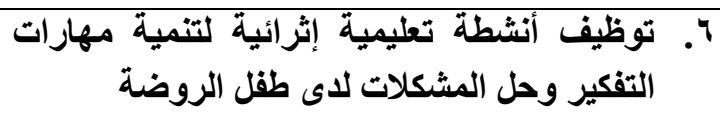 \\
\hline $1 . \cdots$ & $\because \cdots$ & 0. & IV & 0. & IV & $\cdot$ & $\cdot$ & V.طرق تنمية المهارات الحياتية والأدائية للأطفال \\
\hline$\because \cdot \varepsilon$ & $7 . \leqslant 1 \%$ & 0. & iv & ro.r & IT & $1 \leqslant . V$ & 0 & ^. تُجهيز واستخدام ملفات الإنجاز في متابعة أداء \\
\hline$\because \cdots$ & $1 \leq .049$ & $71 . \wedge$ & r) & rq. & $1 \cdot$ & $\wedge . \wedge$ & $r$ & 9. استخدام أساليب متنوعة ومناسبة لتقويم طقل \\
\hline
\end{tabular}

يوضح الجدول السابق إجابات عينة المعلمات على عبارات المجال الثاني: طرق التعليم والتعلم

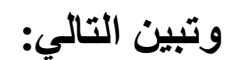
ه توجد فروق بين إجابات العينة للتساؤل الأول (صياغة الأهداف التعليمية و أنو اعها و أساليب قياس

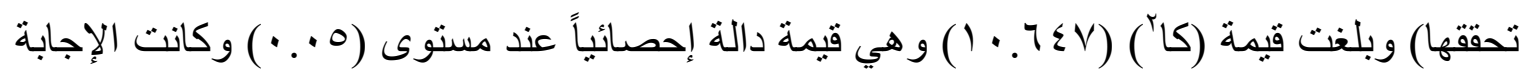

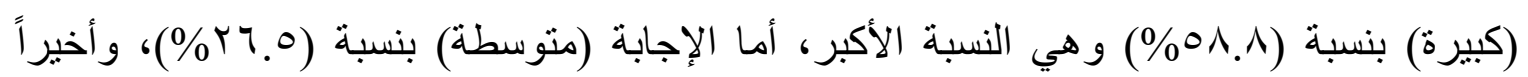

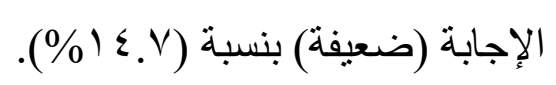

> نوجد فروق بين إجابات العينة للتساؤل الثاني (استخدام أنواع التهيئة والتحفيز المناسبة لطفل

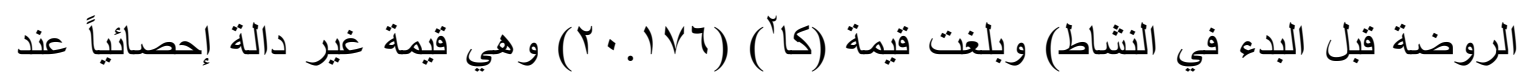

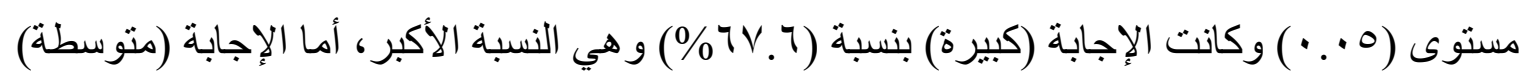

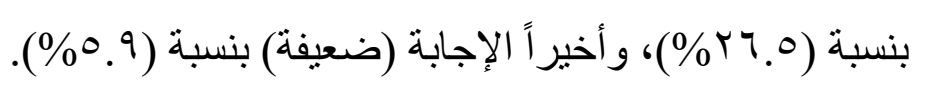

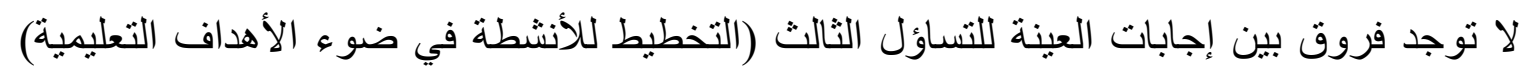

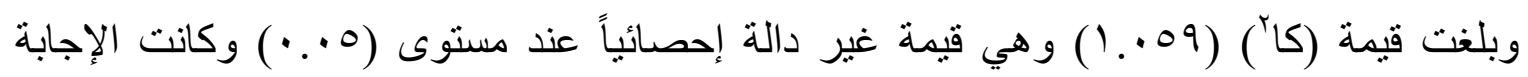

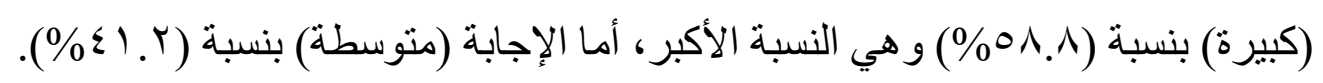

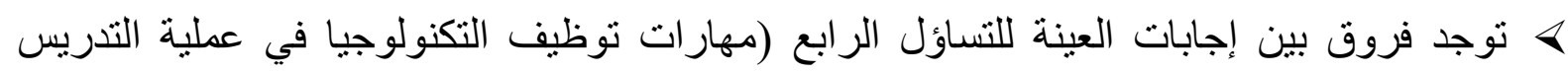

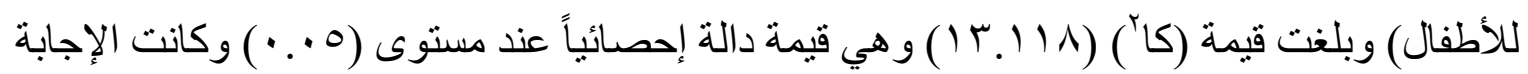


(كبيرة) بنسبة (90\%\%) و هي النسبة الأكبر، أما الإجابة (متوسطة) بنسبة (r.^r\%)، وأخيراً

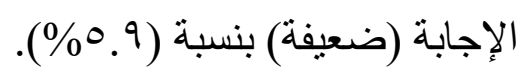

لا توجد فروق بين إجابات العينة للنساؤل الخامس (الاستر اتيجيات الحديثة و الفعالة لتدريس الأطفال) وبلغت قيمة (كاr) (09. . (1) وهي قيمة غير دالة إحصائياً عند مستوى (0. . . ) وكانت الإجابة

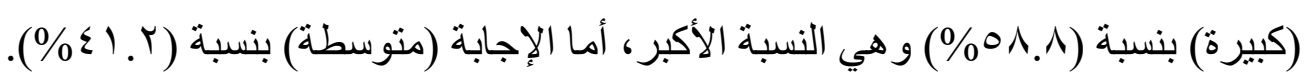

توجد فروق بين إجابات العينة للتساؤل السادس (توظيف أنشطة تعليمية إثرائية لتنمية مهارات

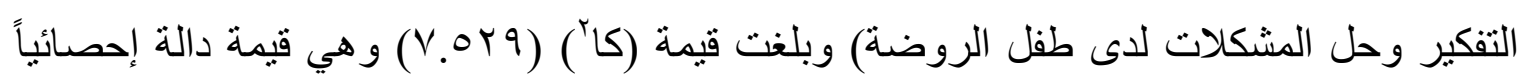

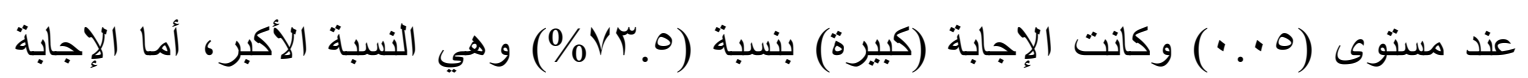

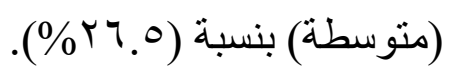

لا نوجد فروق بين إجابات العينة للتساؤل السابع (طرق تتمية المهار ات الحياتية والأدائية للأطفال)

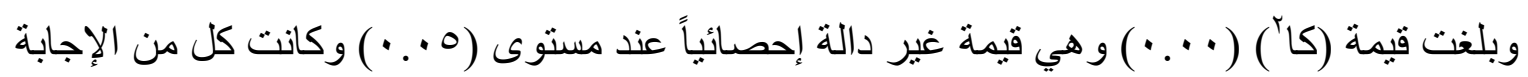

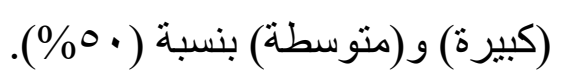

نوجد فروق بين إجابات العينة للتساؤل الثامن (تجهيز واستخدام ملفات الإنجاز في متابعة أداء أطفال

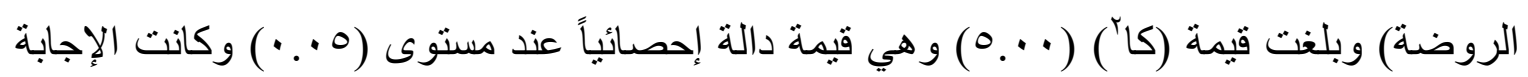

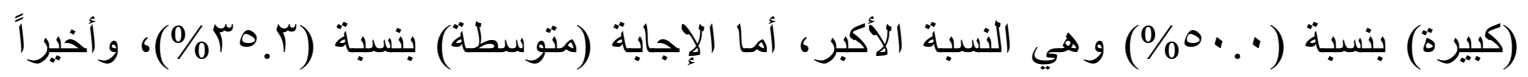

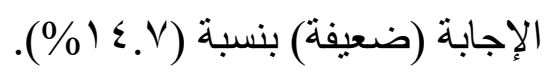

< نوجد فروق بين إجابات العينة للتساؤل التاسع (استخدام أساليب متنوعة ومناسبة لتقويم طفل

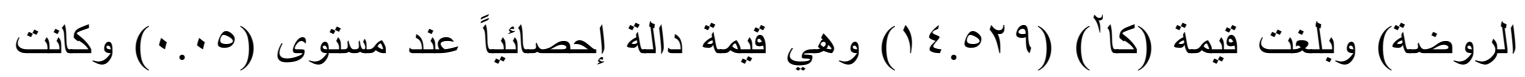

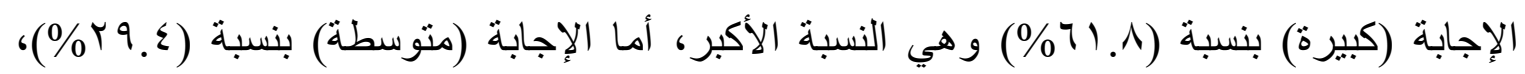

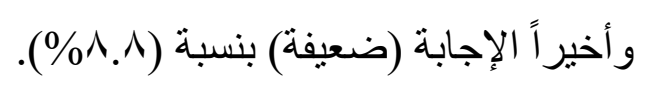


جدول (^) نتائج الإحصاء الوصفي لعبارات عبارات المجال الثاني: طرق التعليم والتعلم

\begin{tabular}{|c|c|c|c|c|}
\hline الترتيب & المئوي الوزني & المعياري & 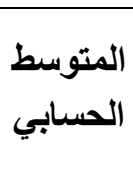 & 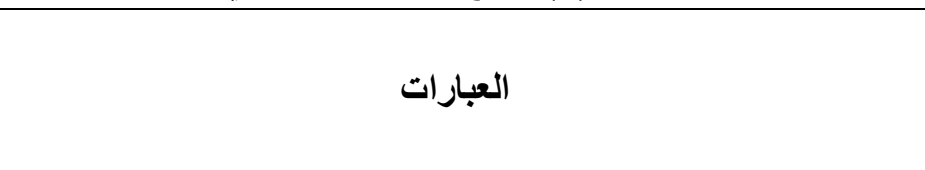 \\
\hline 7 & $\Lambda 1 . r$ & $\because$ Vo & r. $\leqslant \varepsilon$ & ا. صياغة الأهداف التعليمية وأنواعها وأساليب قياس تحققها \\
\hline r & AV.r & $\cdot 7$. & T.TY & ץ. البتخدام أنواع التهيئة والتحفيز المناسبة لطفل الروضة قبل \\
\hline r & ᄉ५.r & $\because 0$ & Y.09 & r. التخطيط للأنشطة في ضو و الأهداف التعليمية \\
\hline 0 & Ar.r & 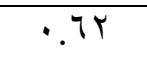 & Y.o. & ؛. مهارات توظيف التكنولوجيا في عملية التدريس للأطفال \\
\hline$r$ & ᄉ५.r & $\because 0$ & r.09 & •. الاستراتيجيات الحديثة و الفعالة لتدريس الأطفال \\
\hline 1 & $91 . r$ & $\because \leqslant 0$ & Y.V & ؟. توظيف أنشطة تعليمية إثرائية لتنمية مهارات التفكير وحل \\
\hline 0 & Ar.r & .01 & T.O. & V. . . طرق تنمية المهارات الحياتية والأدائية للأطفال \\
\hline $\mathrm{V}$ & $\nabla \wedge . r$ & $\cdot V T$ & r.ro & ^.تجهيز واستخدام ملفات الإنجاز في متابعة أداء أطفال الروضة \\
\hline$\varepsilon$ & $\Lambda \varepsilon, r$ & .77 & Y.or & 9. استخدام أساليب متنوعة ومناسبة لتقويم طقل الروضة \\
\hline 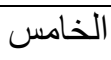 & A & .09 & Y.0ई & المجال الثاني: طرق التعليم والتعلم \\
\hline
\end{tabular}

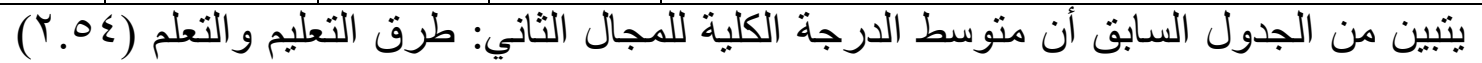

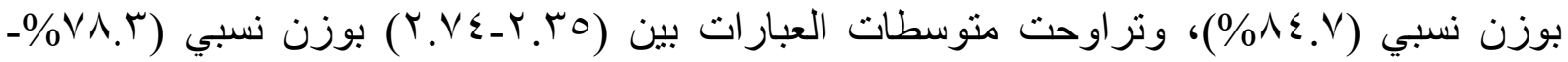
r. (9\%) تشير تللك النسب إلى موافقة عينة الدراسة على عبار ات المجال الثاني: طرق التعليم والتعلم وكان ترتيب أهمية المجال بالنسبة لمجالات الاستمارة الخامس.

التساؤل الثالث: ما الاهتياجات التدربيبية المتعلقة بإدارة البيئة الصفية؟ جدول (9) يوضح الأعداد و النسب وقيمة كا` لاججابات عينة المعلمات على عبارات المجال الثالث: إدارة البيئة الصفية

\begin{tabular}{|c|c|c|c|c|c|c|c|c|}
\hline \multirow{2}{*}{ المعنوية - الدالة } & \multirow{2}{*}{ كا r } & \multicolumn{2}{|c|}{ 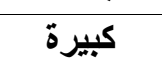 } & \multicolumn{2}{|c|}{ متوسطة } & \multicolumn{2}{|c|}{ ضعيفة } & \multirow{2}{*}{ 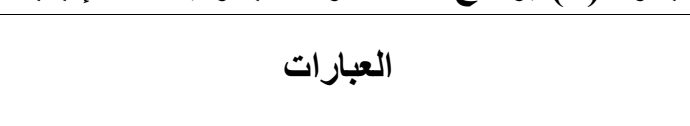 } \\
\hline & & $\%$ & s & $\%$ & ك & $\%$ & ك & \\
\hline$\because 9$ & $r .9 \leq 1$ & $T \leqslant . V$ & rr & ro.r & Ir & • & • & ا الأهداف التعليمية المعلة لمراكز التعلم بما يحقق \\
\hline$\cdot r$ & I.AAr & $7 . \wedge$ & YI & rᄉ. & $1 T$ & - & . & ץ.تنمية مهارات الاستكشاف داخل البيئة الصفية \\
\hline$\cdot r$ & l.AAr & $7 . \wedge$ & $\left(r_{1}\right.$ & rᄉ. & ir & . & . & 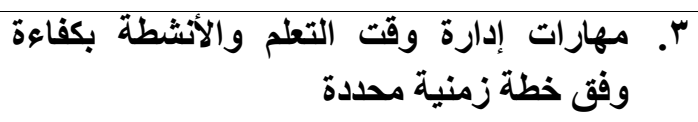 \\
\hline$\because v$ & $9.9 \leq 1$ & 00.9 & 19 & r. & 11 & $11 . \wedge$ & $\varepsilon$ & ؛ ـمهارات تصميم وإنتاج الوسائل التعليمية من \\
\hline .1 & 10.870 & $7 \varepsilon . V$ & rr & rt.o & $\wedge$ & 11.1 & $\varepsilon$ & •.القواعد والقوانين واللوائح المنظمة للعمل \\
\hline
\end{tabular}

الجدول السابق يوضح إجابات لإجابات عينة المعلمات على عبارات المجال الثالث: إدارة البيئة الصفية وتبين التالي:

ه لا توجد فروق بين إجابات العينة للتساؤل الأول (توظيف المعلمة لمر اكز التعلم بما بحقق الأهداف

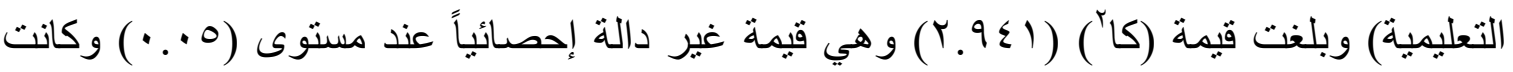

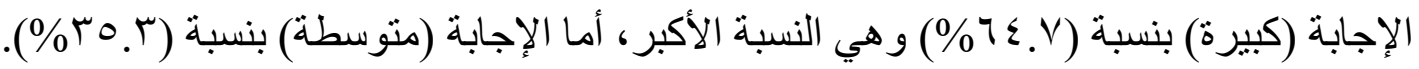


ه توجد فروق بين إجابات العينة للتساؤل الثاني (تنمية مهار ات الاستكثاف داخل البيئة الصفية) وبلغت

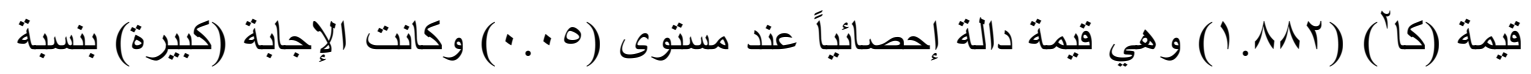

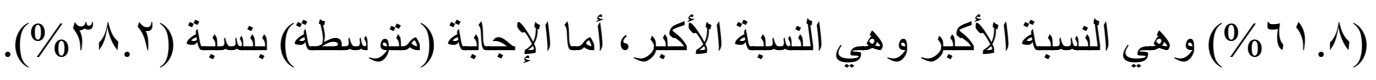
لا توجد فروق بين إجابات العينة للتساؤل الثالث (مهار ات إدارة وقت التعلم والأنشطة بكفاءة وفق

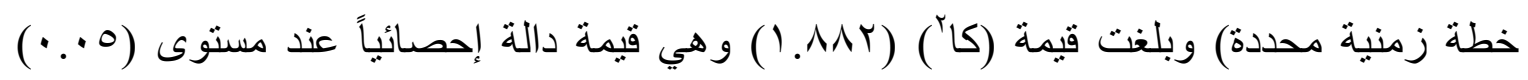
وكانت الإجابة (كبيرة) بنسبة (^.آ٪\%) وهي النسبة الأكبر، أما الإجابة (متوسطة) بنسبة .$(\%$ ( $\%$. r) ه توجد فروق بين إجابات العينة للتساؤل الرابع (مهار ات تصميم و إنتاج الوسائل التعليمية من خامات البيئة) وبلغت قيمة (كاr) (إ؟9.9) و هي قيمة دالة إحصائياً عند مستوى (0. . • ) وكانت الإجابة (كبيرة) بنسبة (9 . \% \%) و هي النسبة الأكبر، أما الإجابة (متوسطة) بنسبة (ع.بr\%). ه توجد فروق بين إجابات العينة للتساؤل الخامس (القو اعد والقو انين و اللوائح المنظمة للعمل برياض

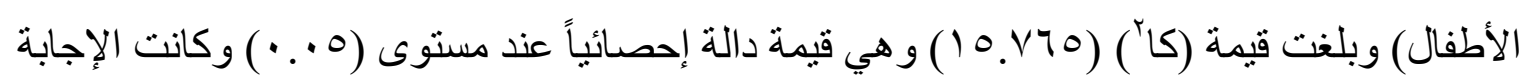

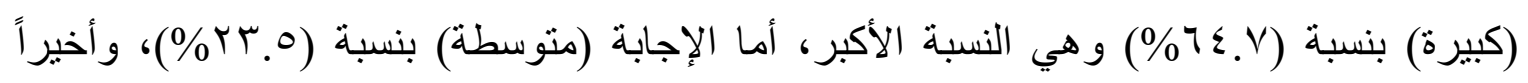

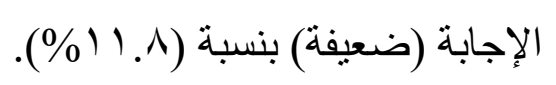

جدول (• 1) نتائج الإحصاء الوصفي لعبارات المجال الثالث: إدارة البيئة الصفية

\begin{tabular}{|c|c|c|c|c|}
\hline الترتيب & النسئي الوزني & المعياري الإنحراف & المستبط & 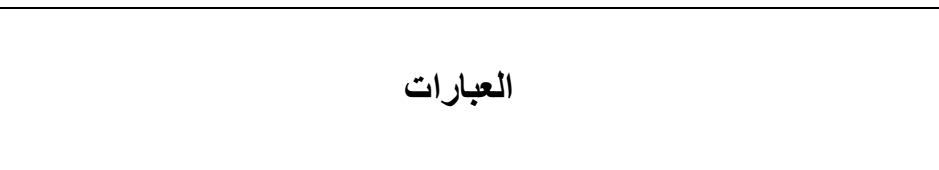 \\
\hline 1 & $\wedge \wedge . r$ & $\because \leqslant 9$ & T.70 & ا . توظيف المعلمة لمر اكز التعلم بما يحقق الأهداف التعليمية \\
\hline r & $\Lambda V^{\prime} r$ &.$\leqslant 9$ & r.Tr & r ب. ت تنمية مهارات الاستكثاف داخل البيئة الصفية \\
\hline r & AV.r & $\because \leqslant 9$ & T.TY & r". مهارةت إدارة وقت التطلم والأنشطة بكفاعة وفق خطة زمنية \\
\hline$\varepsilon$ & A!.r & $\cdot .11$ & T. $\varepsilon \varepsilon$ & ؛. مهارات تصميم وإنتاج الوسائل التعليمية من خامات البيئة \\
\hline$r$ & $\wedge \varepsilon . r$ & $\because \vee 1$ & r.OT & •.القواعد والقو انين واللوائح المنظمة للعمل برياض الأطفال \\
\hline الر ابع & 1०.V & .01 & r.ov & المجال الثالث: إدارة البيئة الصفية \\
\hline
\end{tabular}

يتبين من الجدول السابق أن متوسط الدرجة الكلية للمجال الثالث: إدارة البيئة الصفية (ب.OV.

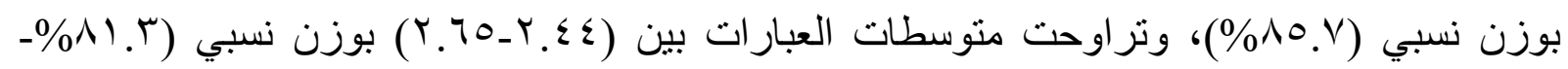
r.ی^\%) تشير تللك النسب إلى مواققة عينة الدراسة على عبارات المجال الثالث: إدارة البيئة الصفية وكان ترتيب أهمية المجال بالنسبة لمجالات الاستمارة الرابع. 


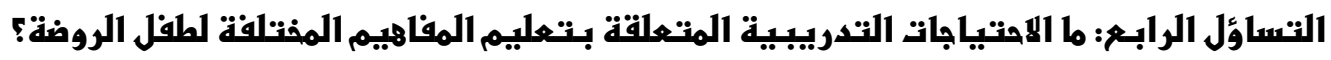
جدول (1 1 ) يوضح الأعداد والنسب وقيمة كا؟ لإجابات عينة المعلمات على عبارات المجال الرابع: تعليم المفاهيم المختلفة لطفل الروضة

\begin{tabular}{|c|c|c|c|c|c|c|c|c|}
\hline \multirow{2}{*}{ 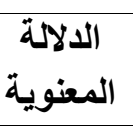 } & \multirow{2}{*}{ rs } & \multicolumn{2}{|c|}{ 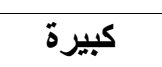 } & \multicolumn{2}{|c|}{ متوسطة } & \multicolumn{2}{|c|}{ ضعيفة } & \multirow{2}{*}{ 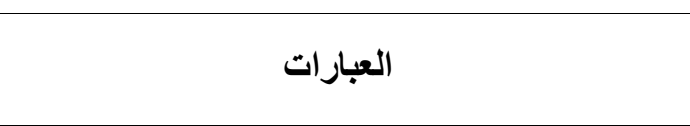 } \\
\hline & & $\%$ & ك & $\%$ & ك & $\%$ & ك & \\
\hline$\because \cdot r$ & $0 . \vee 70$ & $v \cdot .7$ & $r \leq$ & rq. $\varepsilon$ & 1. & • & • & 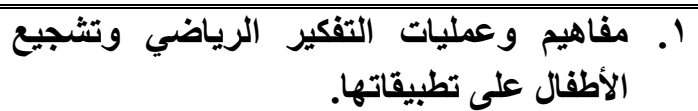 \\
\hline$\because \cdots 1$ & $\varepsilon \vee 1$ & $\varepsilon . \vee$ & YY & r. & 11 & 9 & 1 & ץ.أساليب تهيئة الطقل لتعلم القراعة والكتابة \\
\hline$\cdot r$ & 1.09 & $0 \wedge . \wedge$ & $r \cdot$ & $\varepsilon 1, Y$ & $1 \leqslant$ & • & · & r. مفاهيم وتجارب علمية وطرق تطيقها \\
\hline$\because \cdot r$ & $0 . \vee 70$ & $v \cdot .7$ & $r \leq$ & rq. & 1. & • & • & ؛. ـ سمات المنهج عالي للجودة المناسب للمرحلة \\
\hline$\because \cdots$ & 14.111 & 00.9 & 19 & r^.r & Tr & 0.9 & r & •.طرق تطبيق المفاهيم الاينية والاجتماعية لطفل \\
\hline$\because \cdots 1$ & $r Y . \wedge Y \leq$ & $v \cdot .7$ & $r \varepsilon$ & rT.O & $\Lambda$ & 0.9 & r & 7. أدب الطفل وتطبيقاته المختلفة في العملية \\
\hline$\because \cdots 1$ & r9.1V7 & V7.0 & $r 7$ & $1 V .7$ & 7 & 0.9 & $r$ & V. مراعاتها. الفروق الفردية بين أطفال الروضة وطرق \\
\hline$\because \cdots 1$ & $47.9 \leqslant 1$ & $\wedge$ I. $\varepsilon$ & r^ & 11.1 & $\varepsilon$ & 0.9 & $r$ & ^. المهارات الفنية والابداعية والحركية لطفل \\
\hline
\end{tabular}

الجدول السابق يوضح إجابات لإجابات عينة المعلمات على عبارات المجال الرابع: تعليم

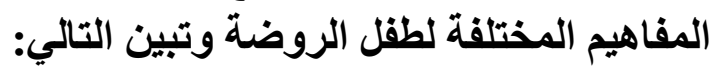
ه توجد فروق بين إجابات العينة للتساؤل الأول (مفاهيم وعمليات التفكير الرياضي وتشجيع الأطفال على تطبيقاتها) وبلغت قيمة (كا؟) (070. V70) و هي قيمة دالة إحصائياً عند مستوى (0. . •) وكانت

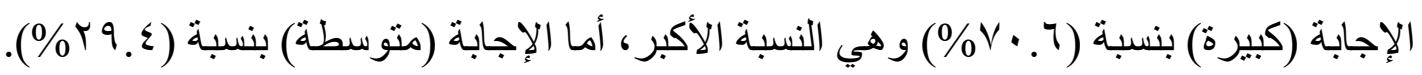
توجد فروق بين إجابات العينة للتساؤل الثاني (أساليب تهيئة الطفل لتعلم القر اءة و الكتابة) وبلغت قيمة

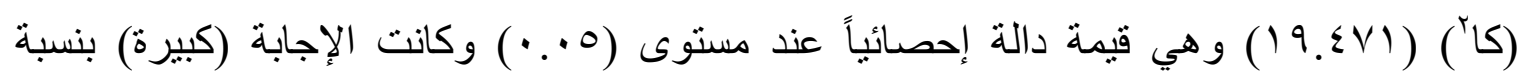

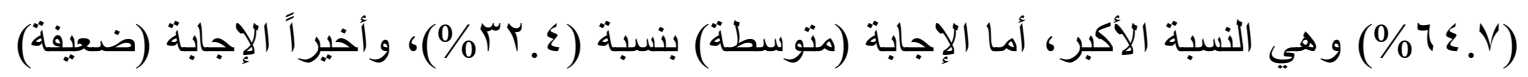

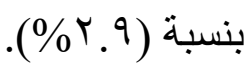
ه لا توجد فروق بين إجابات العينة للتساؤل الثالث (مفاهيم وتجارب علمية وطرق تطبيقها بالروضة) وبلغت قيمة (كا') (09. . (1) وهي قيمة غير دالة إحصائياً عند مستوى (0. . •) وكانت الإجابة

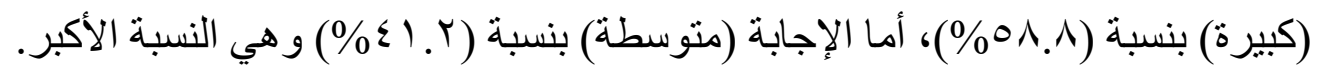
ه توجد فروق بين إجابات العينة للتساؤل الرابع (سمات المنهج عالي للجودة المناسب للمرحلة العمرية للأطفال) وبلغت قيمة (كاr) (070. VT) وهي قيمة دالة إحصائياً عند مستوى (0 . . ) وكانت الإجابة

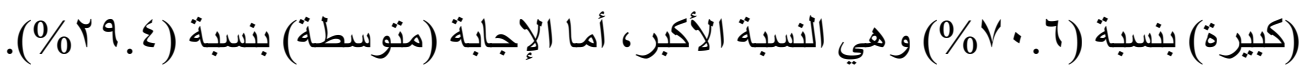


ه توجد فروق بين إجابات العينة للتساؤل الخامس (طرق تطبيق المفاهيم الدينية والاجتماعية لطفل

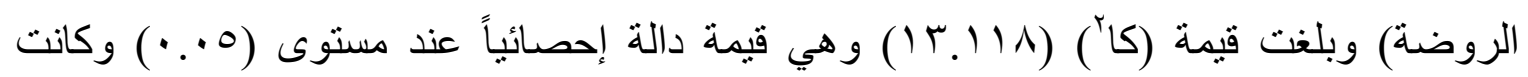

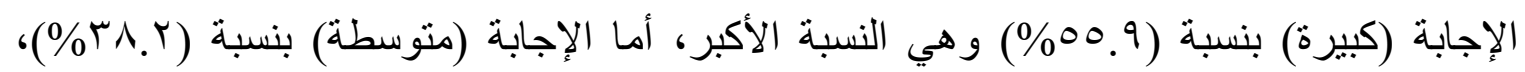

$$
\text { و أخير اً الإجابة (ضعيفة) بنسبة (9.9\%). }
$$

ه توجد فروق بين إجابات العينة للنساؤل السادس (أدب الطفل وتطبيقاته المختلفة في العملية التعليمية)

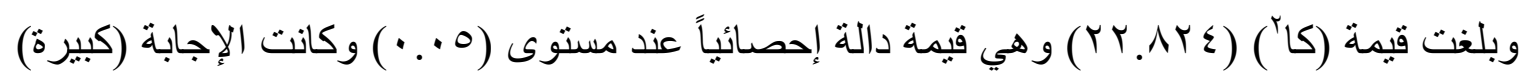

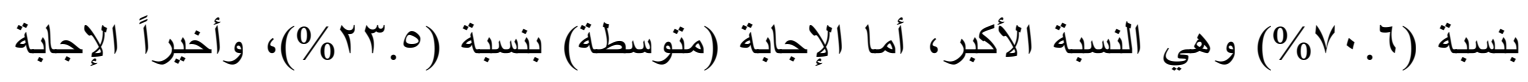
(ضعيفة) بنسبة (9.9\%).

كا توجد فروق بين إجابات العينة للتساؤل السابع (الفروق الفردية بين أطفال الروضة وطرق مر اعاتها) وبلغت قيمة (كاr) (Y (Y . VT) و هي قيمة دالة إحصائياً عند مستوى (0 . . ) وكانت الإجابة (كبيرة)

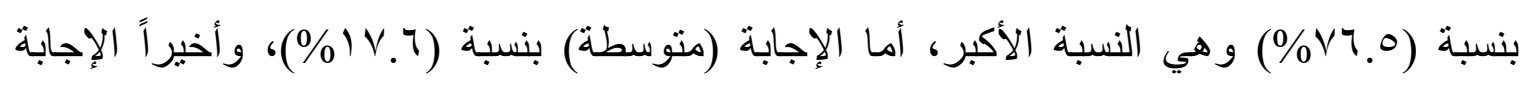

$$
\text { (ضعيفة) بنسبة (9.9\%). }
$$

توجد فروق بين إجابات العينة للتساؤل الثامن (المهار ات الفنية والابداعية والحركية لطفل الروضة)

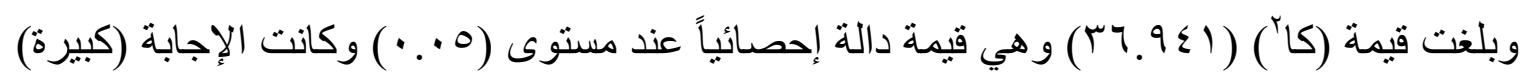

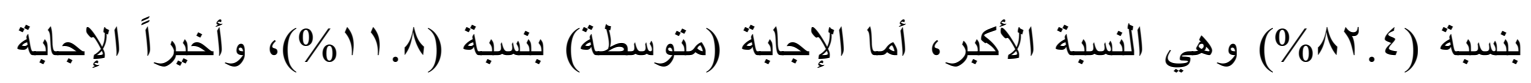

$$
\text { (ضعيفة) بنسبة (9.9\%). }
$$

\begin{tabular}{|c|c|c|c|c|}
\hline الترتيب & النسئي الوزي & 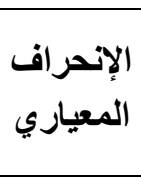 & المستبط & 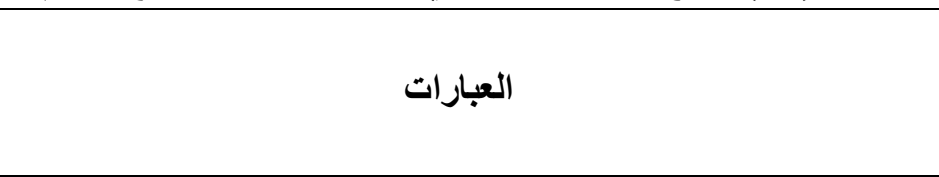 \\
\hline 1 & $9 \cdot r$ & 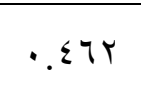 & r.VI & l. مفاهيم وعمليات التفكير الرياضي وتثجيع الأطفال على \\
\hline$\mu$ & $\Lambda V^{r}$ & .001 & r.Tr & r ب. أساليب تهيئة الطفل لتعلم القراعة والكتابة \\
\hline$\varepsilon$ & $\wedge \uparrow . r$ & .0 & r.09 & "r. مفاهيم وتجارب علمية وطرق تطبيقها بالروضة \\
\hline 1 & $9 \cdot . r$ &.$\leqslant 7 r$ & r.VI & ؛. سمات المنهج عالي للجودة المناسب للمرحلة العمرية للأطفال \\
\hline 0 & Ar.r & .710 & T.O & ه. طرق تطبيق المفاهيم الدينية والاجتماعية لطقل الروضة \\
\hline T & $\wedge \wedge . r$ & $.09 \mathrm{~V}$ & T.70 & جا. أدب الطقل وتطبيقاته المختلفة في العملية التعليمية \\
\hline 1 & $9 \cdot . r$ & $.0 \vee 9$ & Y.VI & V الفروق الفردية بين أطفال الروضة وطرق مراعاتها \\
\hline 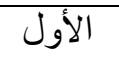 & qr. & $.00 \leqslant$ & Y.VT & المجال الرابع: تعليم المفاهيم المختلفة لطقل الروضة \\
\hline
\end{tabular}

جدول (r I ) نتائج الإحصاء الوصفي لعبارات المجال الرابع: تعليم المفاهيم المختلفة لطقل الروضة

يتبين من الجدول السابق أن متوسط الدرجة الكلية للمجال الرابع: تعليم المفاهيم المختلفة لطفل الروضل

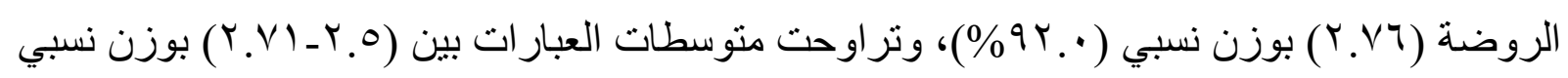




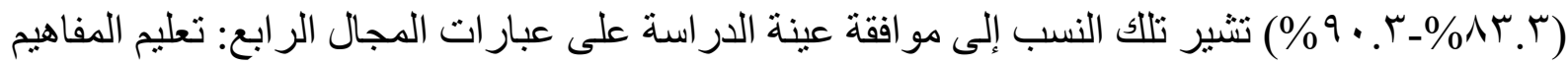
المختلفة لطفل الروضة وكان ترتيب أهية المجال بالنسبة لمجالات الاستمارة الأول.

التساؤل الفامسر: ما الاهتياجات التدريبية المتعلقة بـالتنمية المهنية لمعلمة الروضة؟

جدول (r 1 ) يوضح الأعداد والنسب وقيمة كا` لإجابات عينة المعلمات على عبارات المجال الخامس: التنمية المهنية

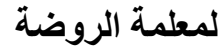

\begin{tabular}{|c|c|c|c|c|c|c|c|c|}
\hline \multirow{2}{*}{ المعالة المية } & \multirow{2}{*}{ Sir } & \multicolumn{2}{|c|}{ كبيرة } & \multicolumn{2}{|c|}{ متوسطة } & \multicolumn{2}{|c|}{ ضعيفة } & \multirow{2}{*}{ 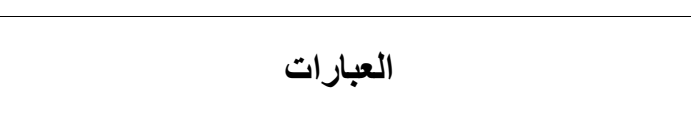 } \\
\hline & & $\%$ & ك & $\%$ & ك5 & $\%$ & ك5 & \\
\hline$\because r$ & $1 . \wedge \wedge r$ & $71 . \wedge$ & $r_{1}$ & ५А. r & r & $\cdot$ & $\cdot$ & ا ـ مهارة اكتثاف ورعاية المتفوقين والموهوبين \\
\hline$\because \varepsilon$ & E.TMO & $7 V .7$ & Tr & Tr.s & 11 & . & $\cdot$ & 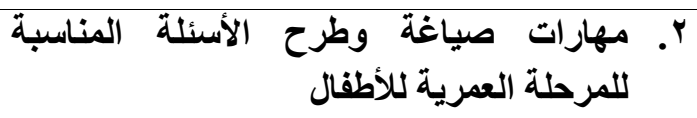 \\
\hline.$V$ & .111 & or.q & 11 & $\left.\leqslant V_{.}\right)$ & 17 & $\cdot$ & · & r. أساسيات ومهارات البحث العلمي في رياض \\
\hline$\because 9$ & $r .9 \leq 1$ & $7 \leqslant . V$ & Tr & ro.r & IT & $\cdot$ & $\cdot$ & ؛. الثقافة الغذائية والمحافظة على أمن وسلامة \\
\hline$\because \cdots 1$ & $1 \leq . r_{0}$ & $\wedge r_{.} \varepsilon$ & $r \wedge$ & $1 V .7$ & 7 & . & $\cdot$ & •.معايير وآداب وأخلاقيات المهنة \\
\hline$\because \cdots 1$ & $19 . \wedge \wedge r$ & $\wedge \Lambda . Y$ & $r$. & $11 . \wedge$ & $\varepsilon$ & $\cdot$ & $\cdot$ & 7. حاجتك لمعرفة المهارات القيادية والإدارية بما \\
\hline
\end{tabular}

الجدول السابق يوضح إجابات لإجابات عينة المعلمات على عبارات المجال الخامس: التنمية

المهنية لمعلمة الروضة وتبين التالي:

ه لا توجد فروق بين إجابات العينة للتساؤل الأول (مهارة اكتشاف ور عاية المتفوقين و المو هوبين من

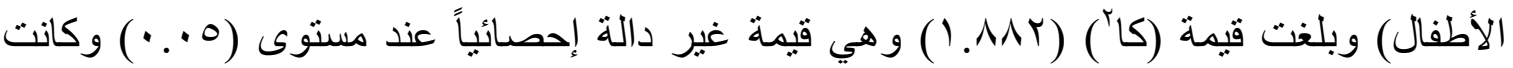

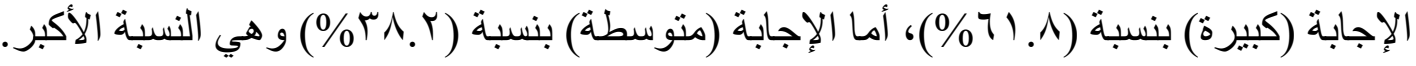
ه توجد فروق بين إجابات العينة للتساؤل الثاني (مهار ات صياغة وطرح الأسئلة المناسبة للمرحلة

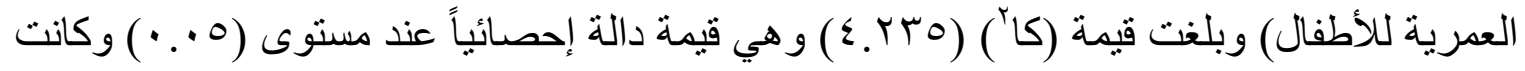
الإجابة (كبيرة) بنسبة (T.T\%\%) و هي النسبة الأكبر ، أما الإجابة (متوسطة) بنسبة (ع.ب\%\%). ه لا توجد فروق بين إجابات العينة للتساؤل الثالث (أساسيات ومهار ات البحث العلمي في رياض الأطفال) وبلغت قيمة (كا؟) (11 (1. •) وهي قيمة غير دالة إحصائياً عند مستوى (0.. • ) وكانت

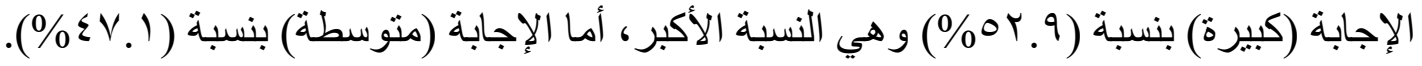
ه ل الوجد فروق بين إجابات العينة للتساؤل الر ابع (الثقافة الغذائية و المحافظة على أمن وسلامة الطفل) وبلغت قيمة (كا'r) (1 (Y.9) وهي قيمة غير دالة إحصائياً عند مستوى (0. . •) وكانت الإجابة

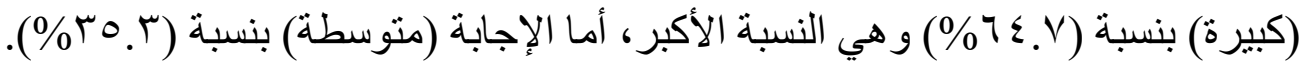


ه توجد فروق بين إجابات العينة للتساؤل الخامس (معايير و آداب وأخلاقيات المهنة) وبلغت قيمة (كا؟)

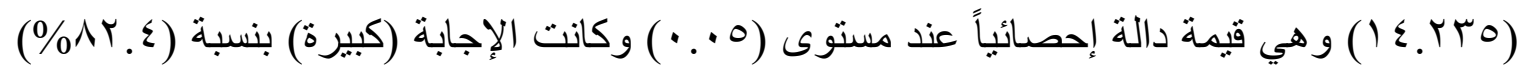

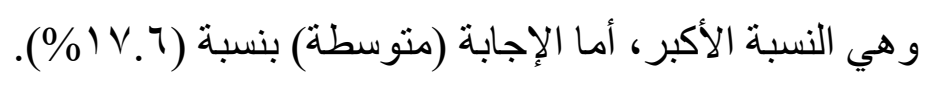

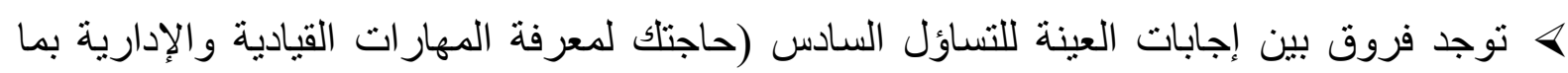

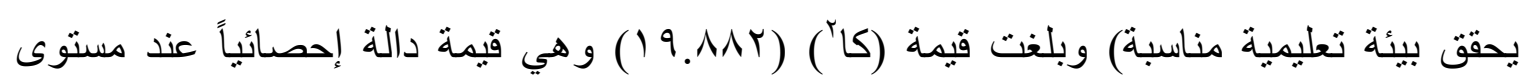

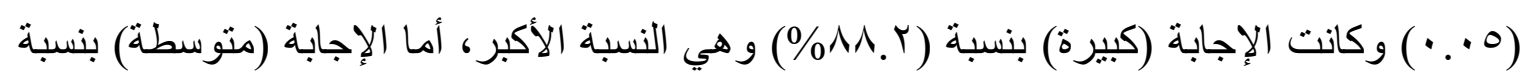

. $(\%) 1 . \wedge)$

جدول ( \& 1) نتائج الإحصاء الوصفي لعبارات المجال الخامس: التنمية المهنية لمعلمة الروضة

\begin{tabular}{|c|c|c|c|c|}
\hline التزتيب & النسبي & المعياري & الحسابي & العبارات \\
\hline$\varepsilon$ & AV.T & $\cdot .29$ & r.Tr & ا. مهارة اكتثاف ورعاية المتفوقين و الموهوبين من الأطفال \\
\hline r & 19. & $\cdot . \leqslant \Lambda$ & r.१ & r. للاطفارات صياغة وطرح الأسئلة المناسبة للمرحلة العمرية \\
\hline ० & $\wedge \varepsilon . \Gamma$ & $\because .01$ & r.or & r. أساسيات ومهارات البحث العلمي في رياض الأطفال \\
\hline$r$ & $\Lambda \wedge . r$ & $\cdot . \leqslant 9$ & T.70 & ـ. الثقافة الغذائية و المحافظة على أمن وسلامة الطقل \\
\hline 1 & 9 9.. & $\cdot .49$ & T.AY & ••.معايير وآداب و أخلاقيات المهنة \\
\hline الثالث & $\lambda \Lambda_{\mathrm{A} . \mathrm{Y}}$ & $\cdot . \leqslant V$ & T.77 & المجال الخامس: التنمية المهنية لمعلمة الروضة \\
\hline
\end{tabular}

يتبين من الجدول السابق أن متوسط الدرجة الكلية المجال الخامس: التنمية المهنية لمعلمة

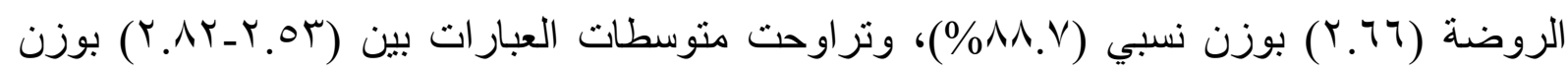

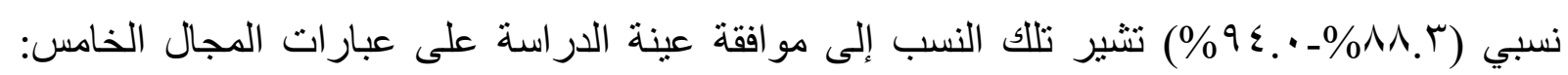
التنمية المهنية لمعلمة الروضة وكان ترتيب أهمية المجال بالنسبة لمجالات الاستمارة الثالث.

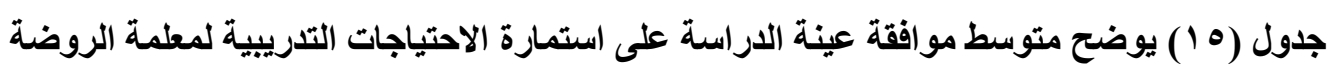

\begin{tabular}{|c|c|c|c|c|}
\hline الترتيب & النئنبي & المعياري الإحراف & الحسابي & المجالات \\
\hline الثاني & $9 \cdot . \cdot$ & $\cdot \varepsilon \mathrm{V}$ & T.V. & المجال الأول: التواصل الفعال مع الأطفال وأسر هم \\
\hline الخامس & $\wedge \Sigma . \vee$ & .09 & Y.0ई & المجال الثاني: طرق التطليم والتطلم \\
\hline 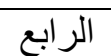 & 10. $\mathrm{Y}$ & .01 & T.OV & المجال الثالث: إدارة البيئة الصفية \\
\hline الأول & $9 r^{\circ} \cdot$ &. $.00 \xi$ & r.V & المجال الرابع: تعليم المفاهيم المختلفة لطفل الروضة \\
\hline الثالث & $\wedge \wedge . \vee$ & 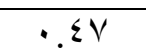 & Y.74 & المجال الخامس: التنمية المهنية لمعلمة الروضة \\
\hline
\end{tabular}

يتبين من الجدول السابق أن المجال الرابع: تعليم المفاهيم المختلفة لطفل الروضة هواء هو أكثر

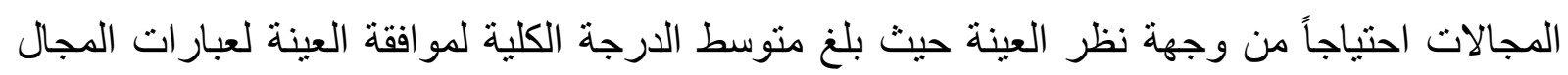

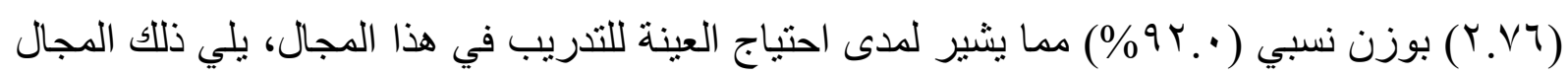

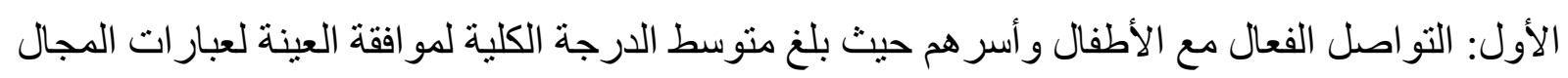




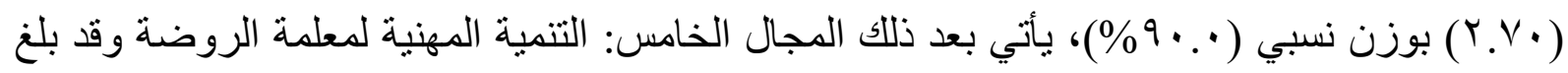

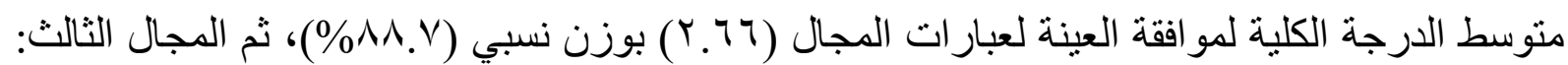
إدارة البيئة الصفية كان منوسط الدرجة الكلية لموافقة العينة لعبارات المجال (Y.OV) بوزن نسبي

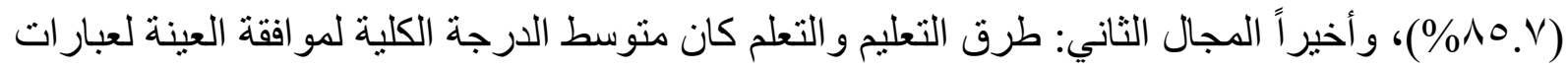

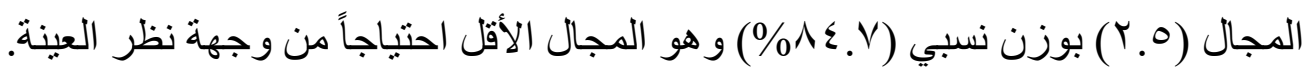

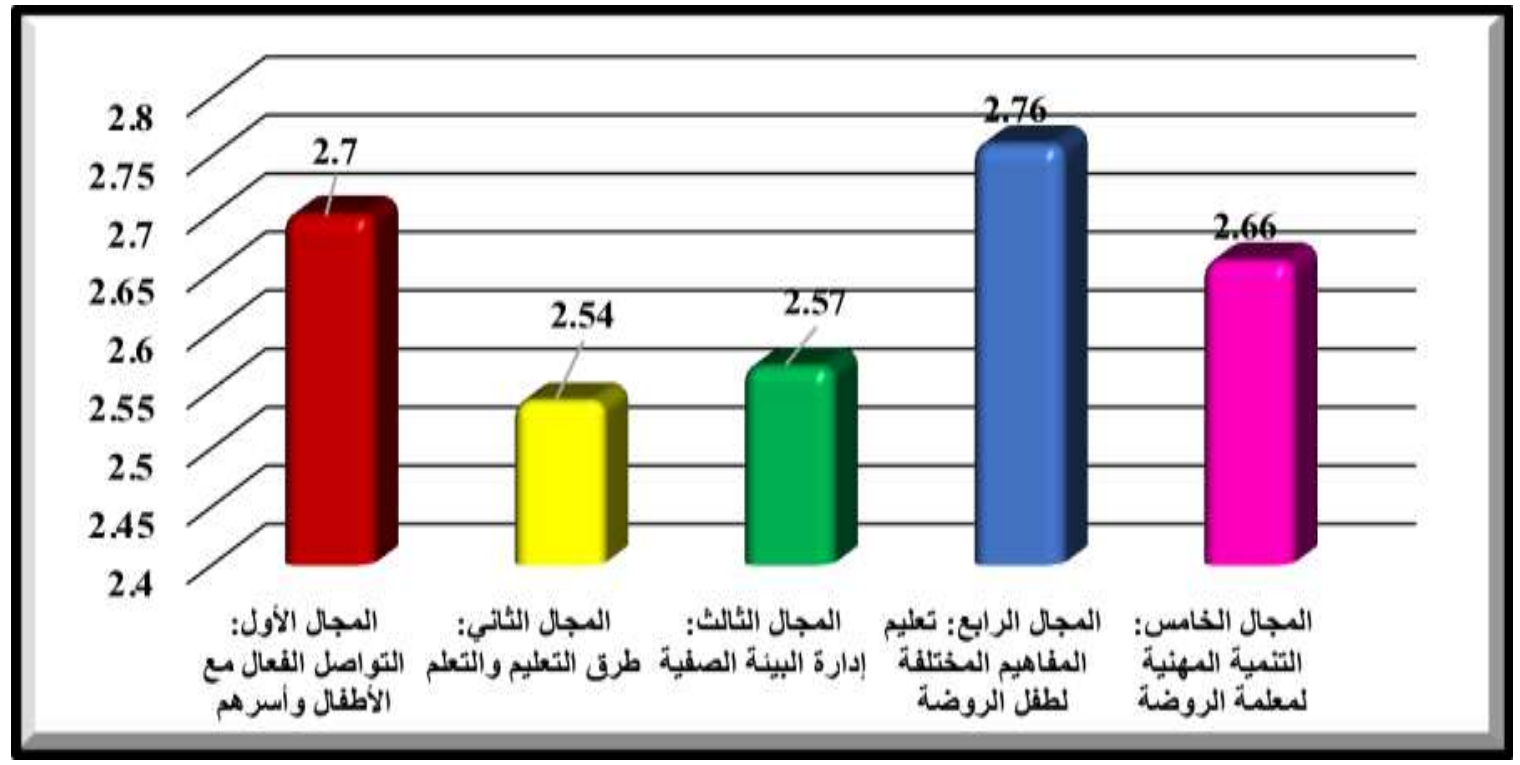

شكل ( ) يوضح متوسطات موافقة عينة الاراسة على استمارة الاحتياجات التدريبية لمعلمة الروضة

\section{نتائج البحث ومناقشتها :}

التساؤل الأول: ما الاحتياجات التدريبية المتعلقة بالتو اصل الفعال مع الأطفال و أسر هم؟ يتبين لنا بأن التساؤل الأول يحتل المرتبة الثانية من بين المر اتب الخمسة بنسبة احتياج تصل إلى ( • . 9\%)، و هذه نسبة مرتفعة جداً تُتبت مدى حاجة المعلمات لهذا النوع من التدريب كما هو موضح في در اسة زكريا (2013). بحيث أكدت أيضاً در اسة صبيرة (2014) على أهمية التو اصل الجيد وما يحققه من أهداف تربوية وتعليمية مساعدة للمعلمة في رفع كفاءة ونجاح العملية التعليمية. التساؤل الثاني: ما الاحتياجات التدريبية المتعلقة بطرق التعليم و التعلم؟

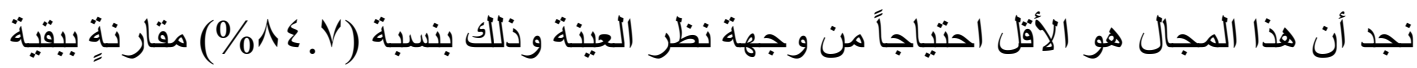
الاحتياجات. ويرجع ذلك للمستوى التعليمي (الجامعي) الذي تحمله كل معلمة رياض أطفال في هذه

الروضات، (Fulghum,2004).

التساؤل الثالث: ما الاحتياجات التدريبية المتعلقة بإدارة البيئة الصفية؟ و هو ما أوضحته در اسة طريف، بحري (2008) بالتأكيد على أن ضعف إدارة البيئة الصفية يقلل من إسهامها في تحقيق أهداف العملية التعليمية، (Ming,2008). التساؤل الر ابع: ما الاحتياجات التدريبية المتعلقة بتعليم المفاهيم المختلفة لطفل الروضة؟ 
تعليم المفاهيم المختلفة لطفل الروضة هو أكثر المجالات احتياجاً من وجهة نظر العينة بنسبة (• ب9\%) مما يشير لمدى احتباج العينة للتدريب في هذا المجال. و هذا ما أكدته در اسة شريف (2011)

التساؤل الخامس: ما الاحتياجات التدريبية المتعلقة برفع التتمية المهنية لدى معلمة الروضة ولئه

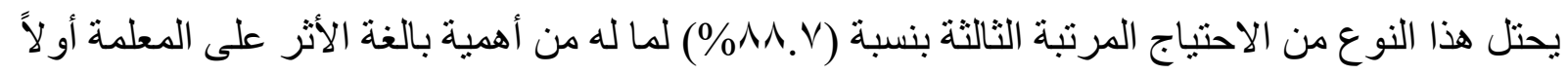

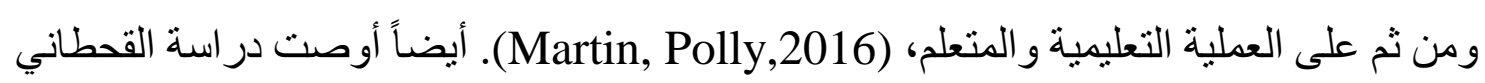
(2020) على ضرورة تصميم بر امج تدريبية ديناميكية تُكن معلمات رياض الأطفال في المملكة العربية السعودية من الالتحاق بها وتنميتهن مهنياً. توصيـات البحث:

1 ضرورة قيام قسم رياض الأطفال بكليات التربية وبالتعاون مع المديرية العامة للتعليم

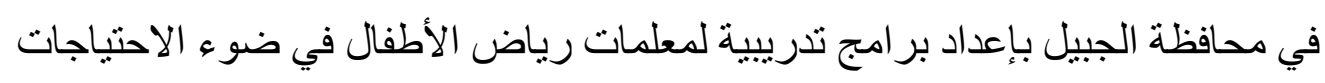
التربوية التي عبر عنها المعلمات

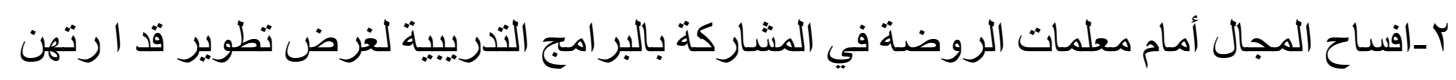
وتتمية كفاياتهن المعرفية والثخصية

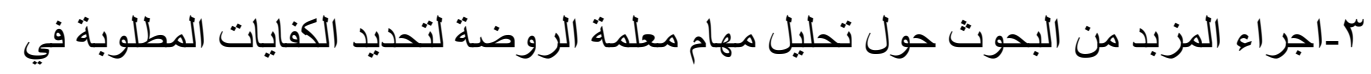
العمل في الروضة وتبني تللك الكفايات ضمن بر امج الإعداد في أقسام رياض الأطفال بكليات

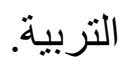

\section{البحوث مقترحسة:}

1- أثر استخدام استر اتيجية مقترحة لتطوير نظم اعداد معلمات رياض الأطفال بكليات التربية

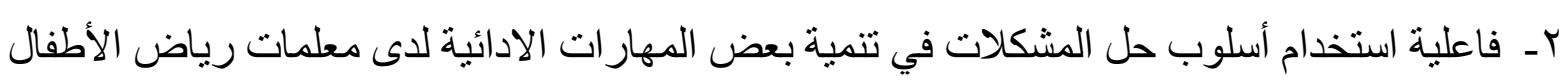

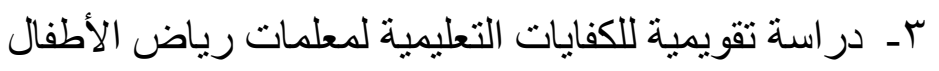
عـ ت تقويم مهار ات معلمات رياض الأطفال 


\section{المراجـع}

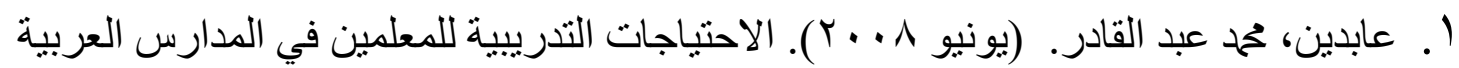

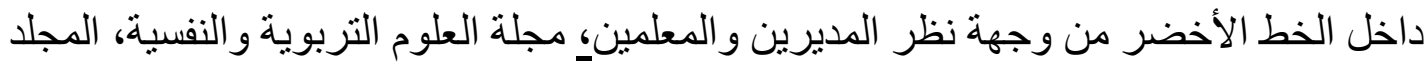

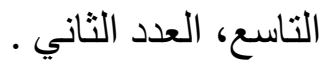

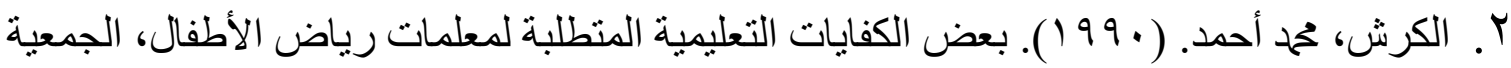

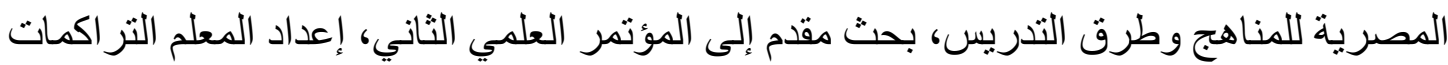

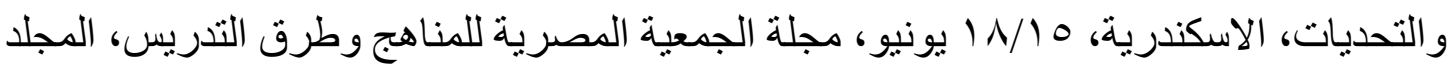
الثاني.

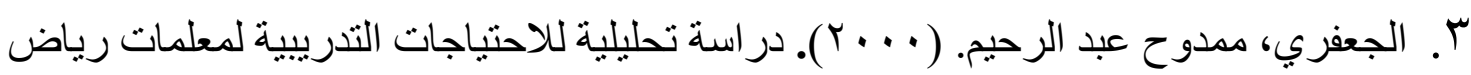

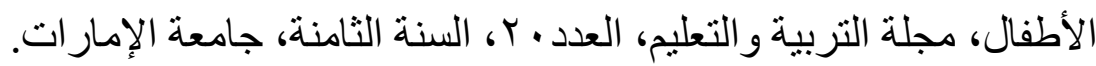

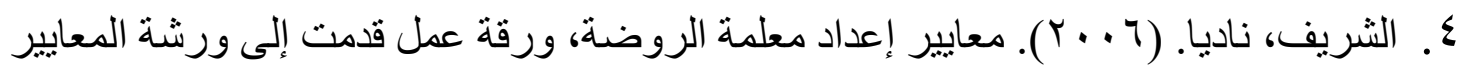

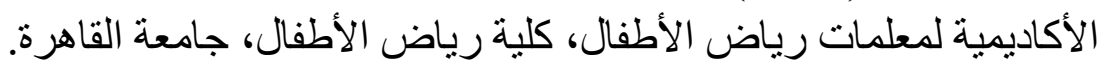

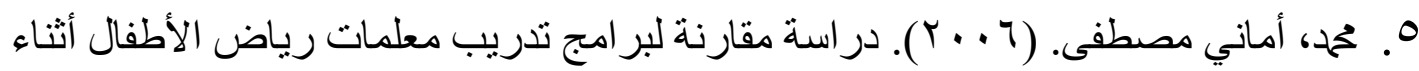

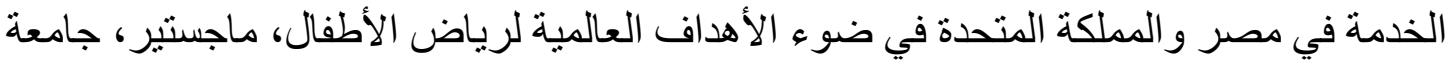
عين شمس، القاهرة.

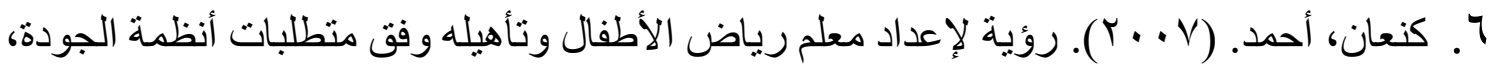

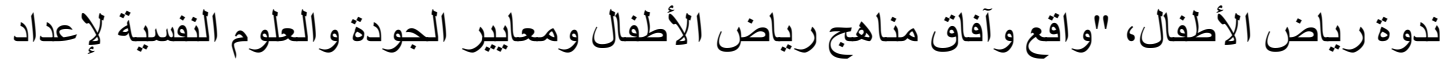

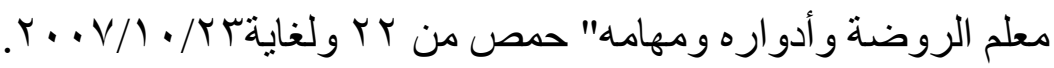

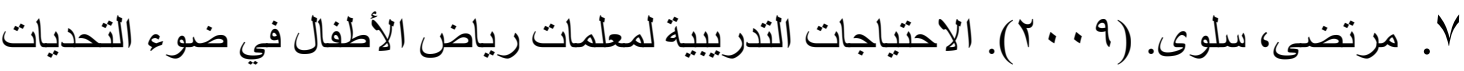

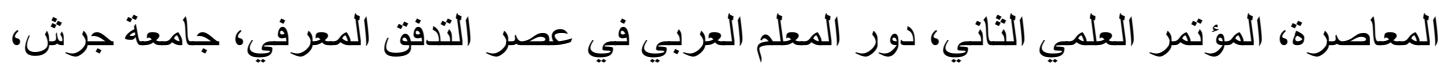

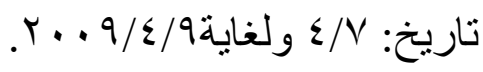

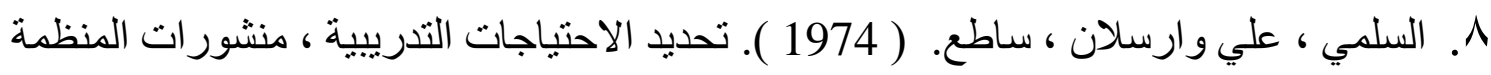

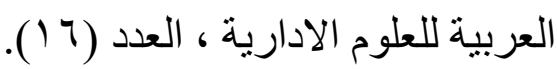

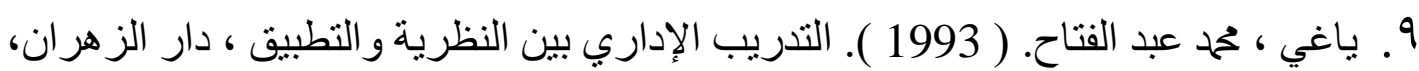
عمان.

• (. ياغي ، محمد عبد الفتاح و عساف ، عبد المعطي. ( 1981 ). مباديء في الإدارة العامة ، مكتب المحتسب ، عمان.

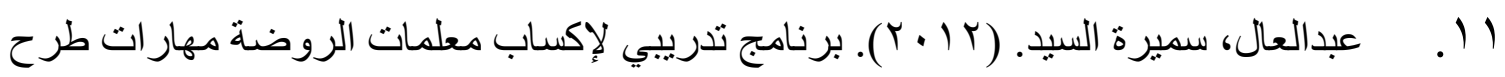

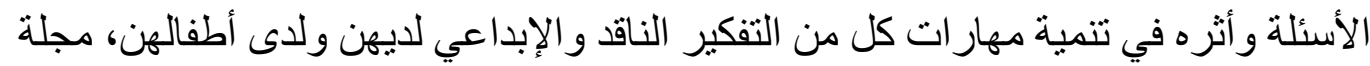
الطفولة ، العدد الحادي عشر.

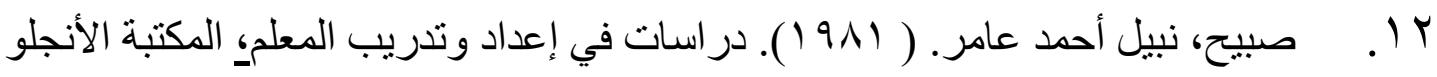
المصرية.

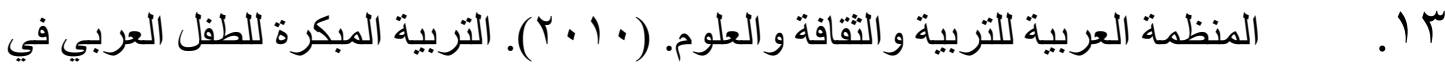
عالم متغير. تونس. 


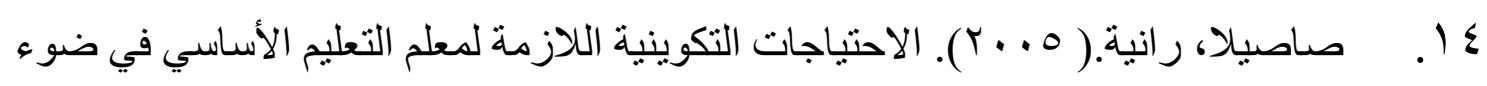

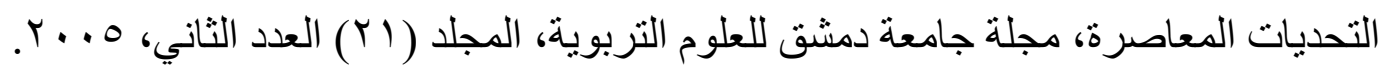

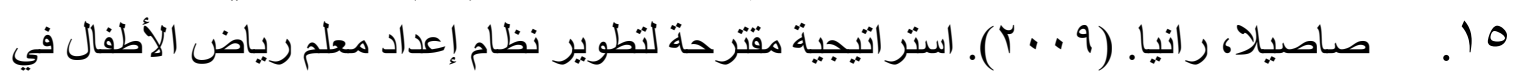

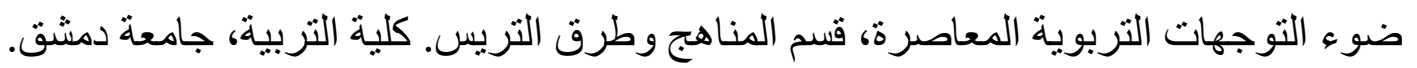

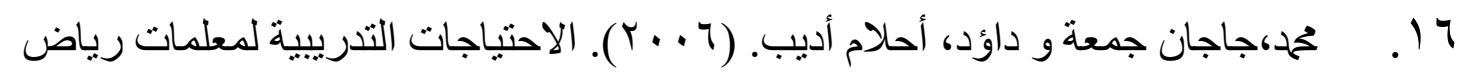
الأطفال من وجهة نظرهن، جانعة الموصل، كلية التربية الاسباسية. IV

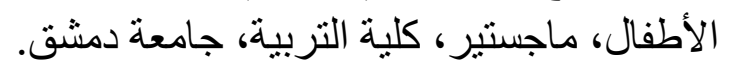

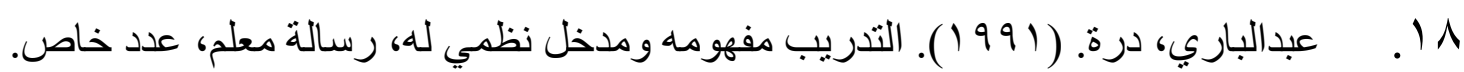

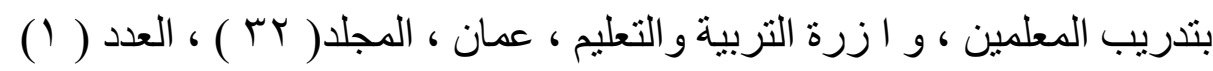

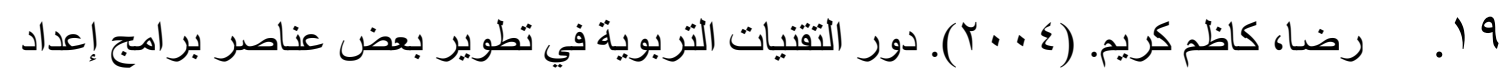

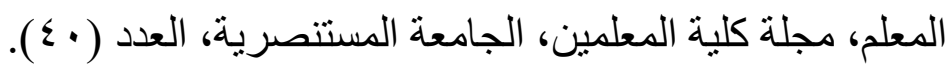

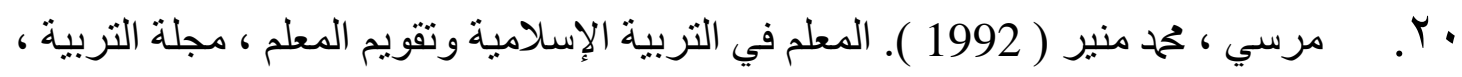

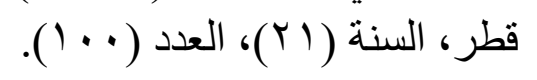

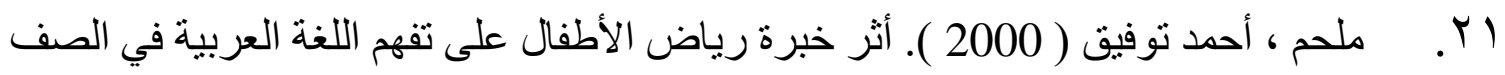

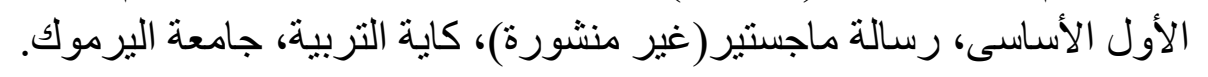

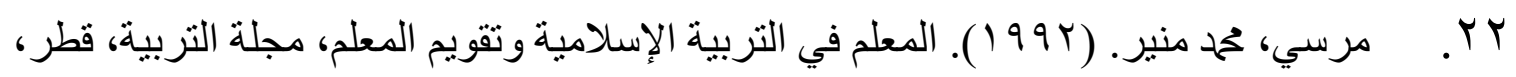

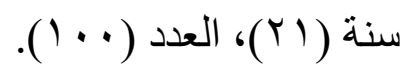

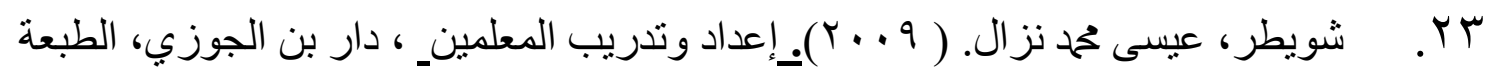

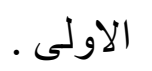

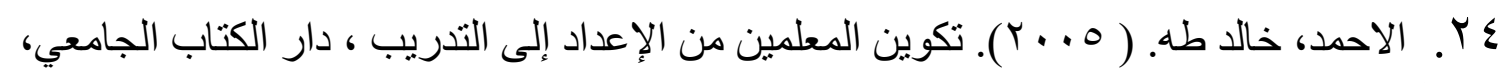
ه ه العين.

ه ب. وزارة التربية و التعليم، البنك الدولي، الأتحاد الأوربي، وحدة التخطيط و المتابعة، برنامج

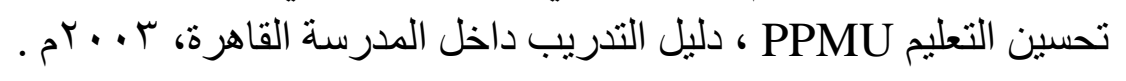

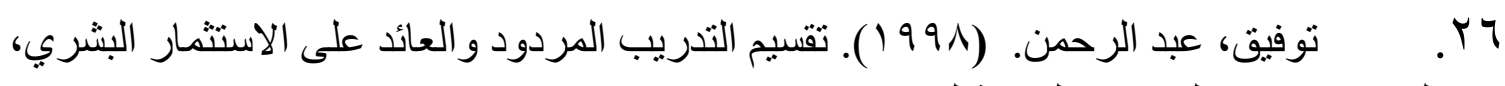

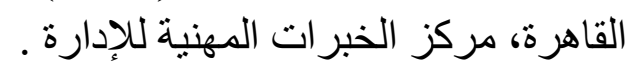
rV

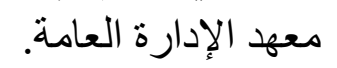

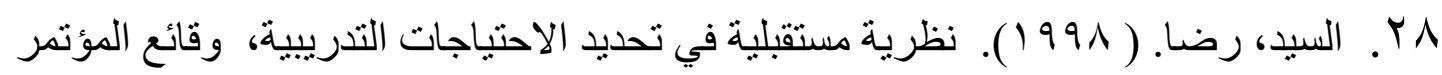

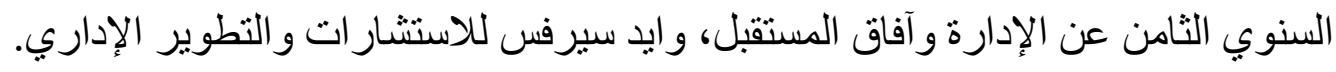

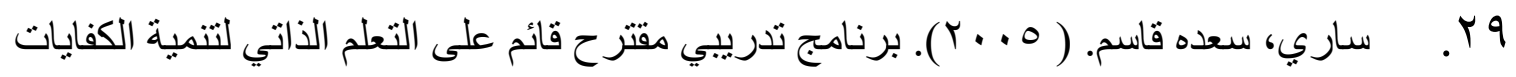

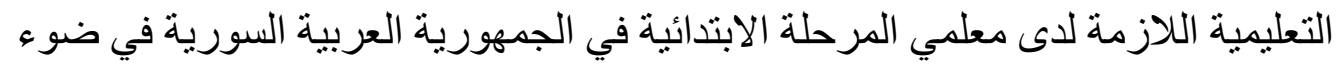

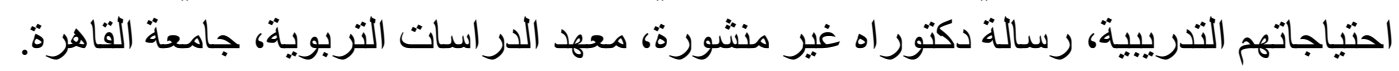




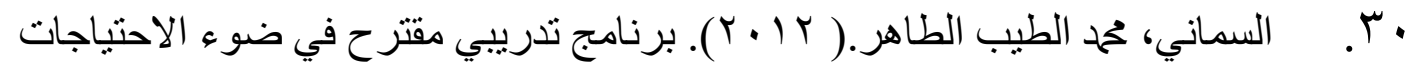

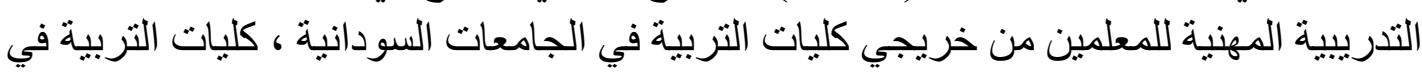

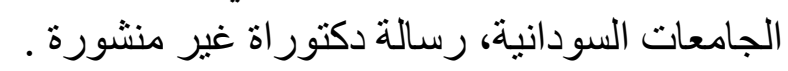

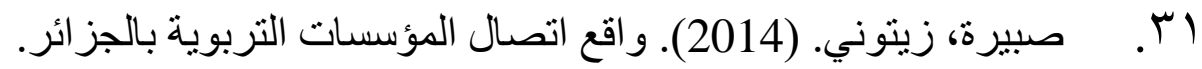
ץT . طريف، عاطف و بحري، منى يونس. (2014). منظومة مقترحة لتقويم أداء الإدارة الصفية في كليات التربية في ضوء معايير الإدارة الصفية الفعالة، جامعة بغدادي، بونية سب. خالد شريف، غصون. (2011). أثز استخدام خر ائط المفاهيم في التحصيل وتعديل قصور الانتباه لاى تلاميذ التربية الخاصنة، جامعة الموصل.

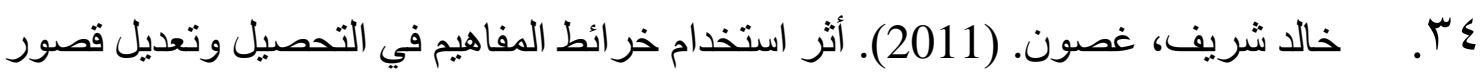

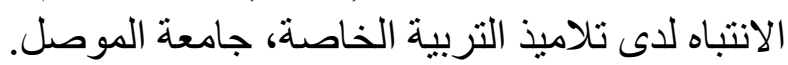
هـ. القحطاني، حنان. (2020). أثر بر امج التنمية المهنية على الأداء التذريسي لمعلمات رياض فئل الأطفال في المملكة العربية السعودية، كلية التربية، جامعة حفر الباطن. جب. شعبان، زكريا. (2013). الحاجات التدريبية الضرورية لدى معلمات رياض الأطفال الحكومية في الأردن، جامعة البلقاء التطبيقية.

\section{ثانيا ــ المراجع الأجنية :}

1-Mauigoa, L, T. (2006). Enhancing Teacher's Questioning Skills to Improve Children's Learning and Thinking in Pacific Island Early

Childhood. New Zeeland Journal of Teachers`Work, Vol.3

Issue1. pp. 12- 23.

2-Kostelnik, M, (1993). Developmentally Appropriate programs in Early

Childhood Education, Macmilan pub.co, New York.

3=Taibot, J. (1995). The Analysis and Costing of Management Training, Management Development and Training Handbook, Mc Graw Hill, New York.

4-Stone, R, (1998). Human Resource Management Jacaranda Wiley

LTD, National Library of Australia \& Melbourne.

5-Galloup, D, and Katherine, B. (2000). On the Job Training_ASTD, Mc

Grow Hill, New York. 
6-Wang, p. (1998). Open Education in Elementary School in Taiwan Teacher Improvement and Training Needs (China), D.AI U.S.A Vol. 59, No3 A, P. 687 in Eric, No, AA 19828296.

7- Fulghum, r, (2004). All I Really Need to Know I Learned in Kindergarten, Ballantine Books, pub.co, New York.

8- Ming, h, (2008). Classroom Management, Creating a Positive Learning Environment. Pub, Hong Kong U.Press, Hong Kong.

9- Martin, c, Polly, d, (2016). Teacher Education and Professional Development. Pub, IGI Global,USA. 